\title{
Field Measurements of the Heating Efficiency of Electric Forced-Air Furnaces in Six Manufactured Homes
}

\author{
Bob Davis \\ Larry Palmiter \\ - Jeff Siegel
}

July 26, 1994

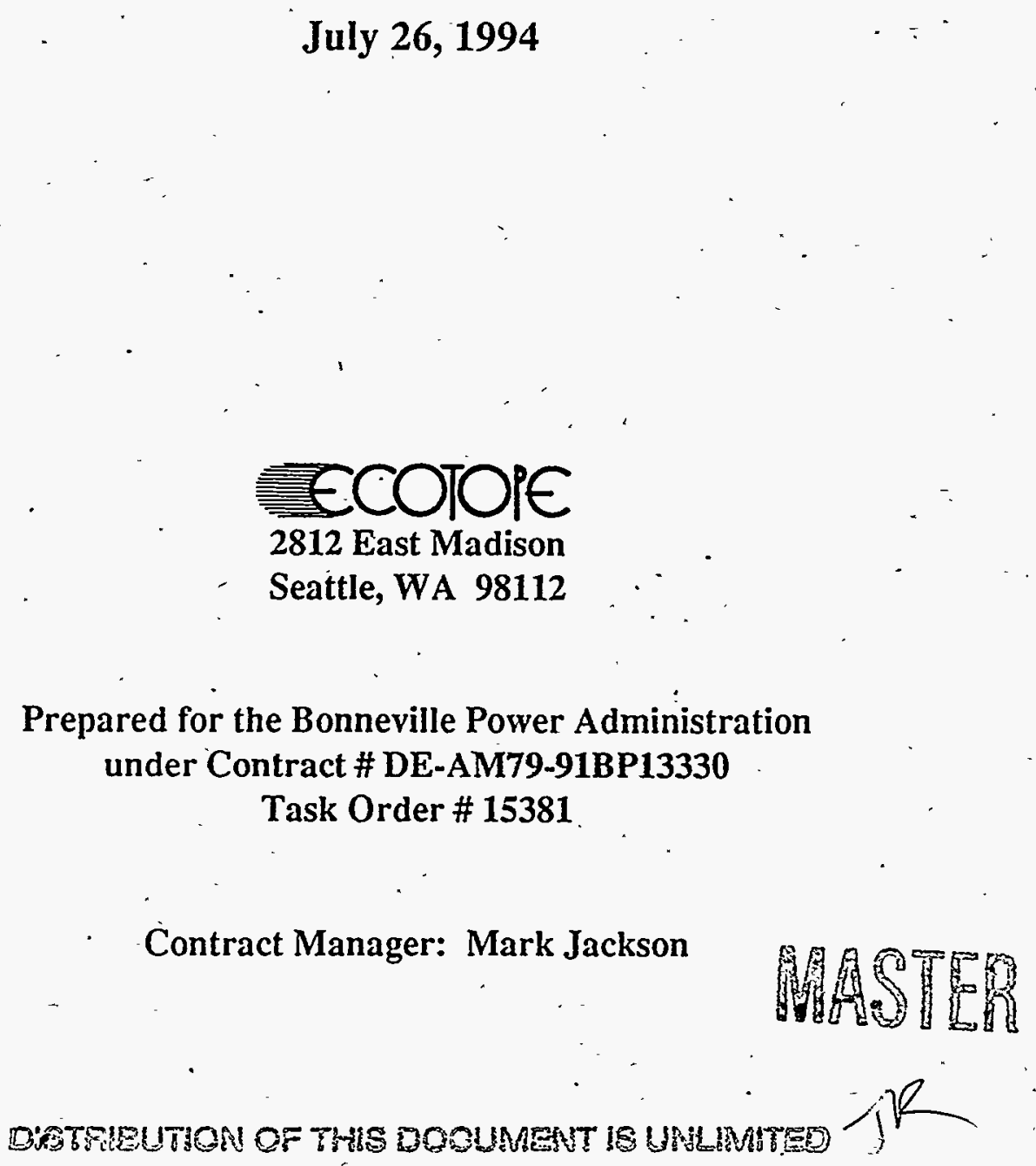




\section{DISCLAIMER}

This report was prepared as an account of work sponsored by an agency of the United States Government. Neither the United States Government nor any agency thereof, nor any of their employees, make any warranty, express or implied, or assumes any legal liability or responsibility for the accuracy, completeness, or usefulness of any information, apparatus, product, or process disclosed, or represents that its use would not infringe privately owned rights. Reference herein to any specific commercial product, process, or service by trade name, trademark, manufacturer, or otherwise does not necessarily constitute or imply its endorsement, recommendation, or favoring by the United States Government or any agency thereof. The views and opinions of authors expressed herein do not necessarily state or reflect those of the United States Government or any agency thereof. 


\section{DISCLAIMER}

Portions of this document may be illegible in electronic image products. Images are produced from the best available original document. 


\section{Executive Summary}

This report presents the results of field measurements of heating efficiency for six manufactured homes in the Pacific Northwest heated with electric forced-air systems ${ }^{1}$. This report is intended to be the first in a series of regional and national efforts to measure in detail the heating efficiency of manufactured homes. Only six homes were included in this study because of budgetary constraints; therefore, this is not a representative sample of manufactured homes. However, these investigations should provide some useful information on the heating efficiency of these homes. Useful comparisons can be drawn between these study homes and site-built heating efficiencies measured with a similar protocol.

The protocol used to test these homes is very similar to another Ecotope protocol used in the study conducted in 1992 and 1993 for the Bonneville Power Administration to test the heating efficiency of 24 homes. This protocol combined real-time power measurements of furnace energy usage with energy usage during co-heat periods. Accessory data such as house and duct tightness measurements and tracer gas measurements were used to describe these homes and their heating system efficiency.

Nationally, manufactured homes account for about $15 \%$ of the existing housing stock, and this proportion is expected to rise. In the Pacific Northwest the percentage of manufactured homes relative to existing single-family housing stock is about $25 \%$. At current production levels, manufactured homes represent about $30 \%$ of new houses being built in this region. Discovering the impacts of forcedair heating systems on overall building energy load is therefore an important undertaking.

Manufactured housing represents the only affordable housing for a large percentage of the population in the United States. The construction, materials and labor costs associated with the housing industry is expected to increase. Ensuring that manufactured housing is constructed in an energy- and resourceefficient manner is of increasing concern to manufactured home builders and consumers.

No comparable work has been done to measure the heating system efficiency of MCS manufactured homes, although some co-heat tests have been performed on manufactured homes heated with natural gas in an attempt to validate HUD thermal standards. It is expected that later in 1994 more research of this kind will be conducted, and perhaps a less costly and less time-consuming method for testing efficiencies will be develops.

The actual heating efficiency was determined in two ways. As defined in Chapter 29 of the 1992 ASHRAE HVAC Systems and Equipment Handbook, the heat delivery efficiency is the amount of total useful heat delivered through the supply registers while the furnace fan is on, divided by the power input to the furnace (including the fan power). The system efficiency is the amount of total useful heat delivered to the conditioned space during the entire period of furnace cycling, divided by the power input to the furnace (including fan power).

Manufactured home duct systems represent a type of heating system that is in between site-built homes, in which ducts are all in unconditioned spaces such as attics and crawl spaces, and houses which have all interior ducts, such as ducts running out of a basement furnace: One would expect heating efficiencies

\footnotetext{
'These homes are built to current Model Conservation Standards, with a $\mathrm{U}_{0}$ of $0.053 \mathrm{Btu} /\left(\mathrm{hr}{ }^{\circ} \mathrm{F}\right)$. Current HUD standards for the Pacific Northwest mandate a $U_{0}$ of $0.079 \mathrm{Btu} /\left(\mathrm{hr}{ }^{\circ} \mathrm{F}\right.$ ). The $\mathrm{U}_{0}$ of a building is its heat loss rate (excluding air infiltration) divided by the area of the building's shell.
} 
of electrically-heated manufactured homes to be somewhere between the efficiencies associated with these aforementioned systems. In fact, this is what was measured. Average adjusted system efficiency was $86 \%$, meaning a ducted home uses 1.16 times as much energy as a home heated with electric baseboards (assuming the baseboards are $100 \%$ efficient).

Preliminary estimates done by Ecotope after review of BPA's initial incentive program for MCS manufactured homes [ Manufactured Homes Acquisition Program (MAP)] suggested that the impact on furnace efficiency from the ducting system was an approximately $4 \%$ to $6 \%$ decrease in efficiency. This estimate was based on a number of assumptions about the ducts' air leakage rate, conductive losses, and changes in pressure inside the envelope and belly cavity area that affect energy usage. In light of the findings of this report, revision of the MAP specifications is in order.

It may be that the only way to eliminate distribution losses would be to remove the forced-air systems completely from manufactured homes and replace them with wall heaters or an internally ducted system. This change would not be practicable in many parts of the country, especially in regions with sizable cooling loads. If this change is made, it is also suggested that a balanced-flow of ventilation system be added to the house. Manufactured homes in this study have average air change rates (even with some added ventilation) at levels considerably below the ASHRAE standard of $0.35 \mathrm{ACH}$. Change in distribution systems cannot be made solely on the basis of energy conservation. They must take into account the financial impacts on manufacturers and the physical limitations of manufacturing plants.

It should be stressed that these results concern only a small subset of manufactured homes. Because the sample size is small, and the population of manufactured homes diverse, the reader should employ the results cautiously. 


\section{TABLE OF CONTEN̦TS}

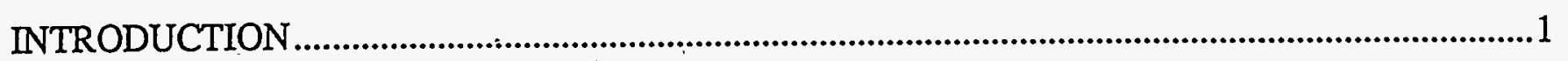

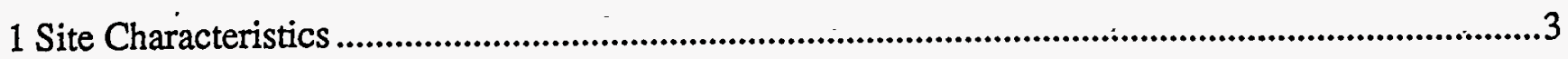

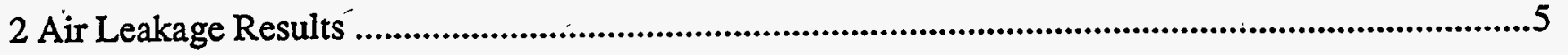

3 Heating System Efficiency ...................................................................................................

4 Furnace Power Summary and Annual Heating Energy Impacts ....................................................15

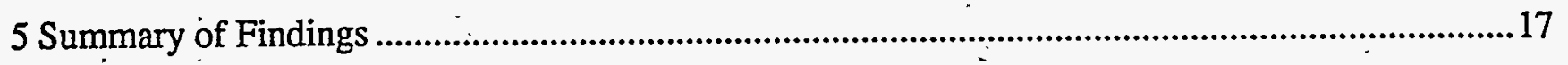

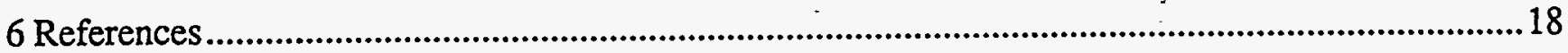

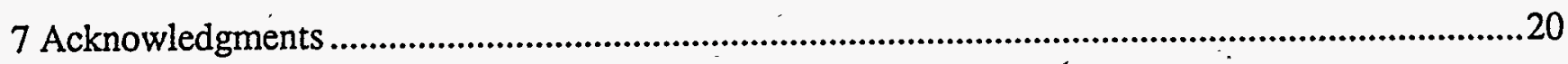

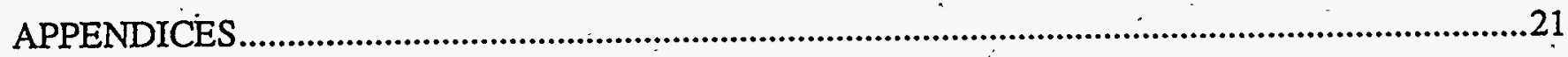




\section{TABLE OF TABLES}

TABLE 1: SITE CHARACTERISTICS

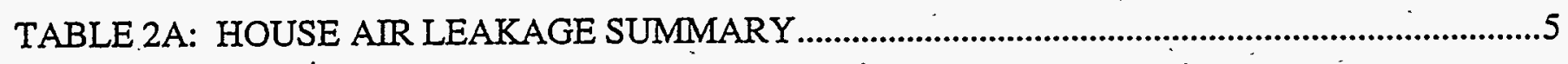

TABLE 2B: COMPARATIVE WHOLE-HOUSE LEAKAGE RATES ................................................6

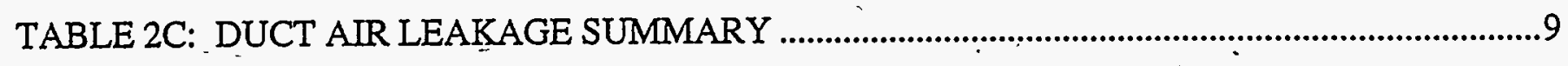

TABLE 3A: HEATING EFFICIENCIES .......................................................................................

TABLE 3B: TEMPERATURES DURING FURNACE CYCLING ......................................................12

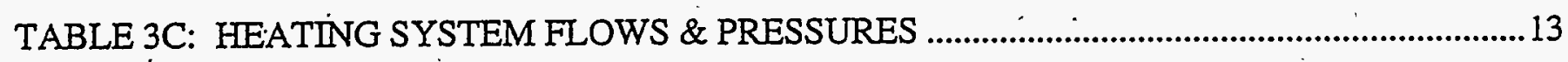

TABLE 3D: MODELED DUCT EFFECTS ON EFFICIENCY ….............................................................

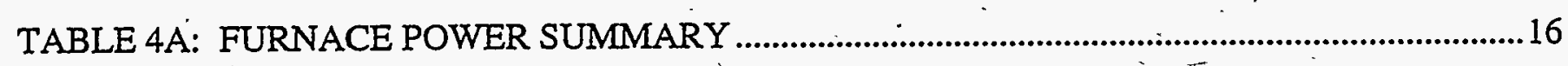

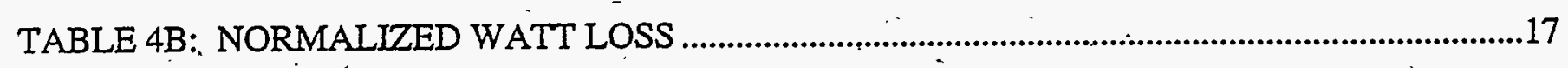




\section{INTRODUCTION}

In the past fifteen years, organized energy conservation efforts have focused primarily on building sheil and air sealing measures, including improved insulation levels and better windows. Researchers and sponsors of conservation programs have only very recently shifted their attention to heating systems and their effect on overall energy usage in the home. There. have been only a handful of reports published on the effects of distribution systems on home energy usage, and these reports have largely ignored manufactured homes.

Various researchers (Modera, 1989; Parker, 1989; and Róbison and Lambert, 1988) have found average decreases of between $10 \%$ and $30 \%$ in heating system efficiency due to conduction losses, air leakage and associated effects. These studies cannot be called representative, however, they do indicate how the effects of heating system distribution can, on average, greatly compromise any improvements made in the homes' insulation levels and envelope tightness.

With the advent of stringent energy codes for both site-built and manufactured homes, it has become increasingly desirable to determine the effects of distribution system losses on the overall building load. In the Pacific Northwest, incentive programs have been operated by the Bonneville Power Administration and local utilities to capture conservation in the manufactured home sector. Many researchers, utility personnel and owners of manufactured homes are interested in the effect of distribution systems on the homes' energy use. Therefore, the results presented in this report represent an important first step in understanding the effects of forced-air electric furnaces in manufactured homes.

The primary findings on heating systems efficiency are discussed in the following sections of this report. For clarity, the findings are presented in a series of tables with accompanying explanatory test. These tables present site characteristics, heating efficiencies, air and duct leakage results, average temperatures in and outside of the home and heating system during tests, heating system pressures and flows, furnace cycling and power loss summaries, and the effect of efficiency losses on the overall heating load.

The heating system efficiency measurements began with a complete house audit. Warm-up tests to measure warm-up efficiency were conducted, although the results of this particular testing are not presented here. The main efficiency test was a short-term alternating co-heat test. This test is described in some detail in the Appendices. Tracer gas decay tests, blower door tests at two pressures, duct tester measurements conducted at two static pressures (for total leakage and leakage to outside of the building envelope) were completed. Some additional tests measuring exhaust fan performance and differential pressurization of the house during air handler operation were also performed.

Because of time and budget constraints, it was not possible to conduct a thorough analysis of the separate effects of conduction and air leakage on efficiency losses in manufactured homes. An estimate is made in this report based on a model described by Palmiter and Bond (1991b). We expect that the data gathered in this-report will be used as part of an expanded mathematical model of duct performance currently under development for the Electric Power Research 
Institute (EPRI) by Larry Palmiter. We could not draw a definite conclusion about the "best" type of floor to use in manufactured homes heated with in-floor ducting. The conclusions will require extensive paired and sequential testing of different floor and duct system designs.

Further research will be conducted under a different contract during the 1994 heating season. This research will be conducted in the Northwest and in North Carolina and New York. This work, together with further revision of Ecotope's duct system modeling, should improve the accuracy of efficiency loss estimates. 


\section{Site Characteristics}

Site characteristics and basic building information are presented in Table 1. The study homes are of basic manufactured home design: rectangular structures with very little, if any, unusual architectural detailing. The majority of the manufactured homes constructed in the Pacific Northwest are double-wide units, generally 1,000 to $1,700 \mathrm{ft}^{2}$ in size. The home is constructed in two halves in the factory; the halves are joined together on-site. Occasionally additional modules are added onto the side of a double-wide, as in the case of Site M03.

\section{TABLE 1: SITE CHARACTERISTICS}

\begin{tabular}{|c|c|c|c|c|c|c|}
\hline Site ID & Width & $\begin{array}{l}\text { Area } \\
{\left[\mathrm{ft}^{2}\right]}\end{array}$ & $\begin{array}{c}\text { Volume } \\
{\left[\mathrm{ft}^{3}\right]}\end{array}$ & $\begin{array}{c}\text { Altitude } \\
{[\mathrm{ft}]}\end{array}$ & $\begin{array}{c}\text { Duct Length } \\
\text { [ft] }\end{array}$ & $\begin{array}{c}\text { Capacity } \\
{[\mathrm{kW}]}\end{array}$ \\
\hline MO1 & 2 & 960 & 7561 & 1750 & 88 & 11.6 \\
\hline M02 & 2 & 1716 & 14586 & .530 & 135 & 15.2 \\
\hline M03 & $2.5^{1}$ & 2038 & 18530 & 50 & 145 & 19.2 \\
\hline M04 & 2 & 1709 & 1.4813 & 250 & 150 & 11.2 \\
\hline M05 & 2 & 1699 & 14144 & 425 & 142 & 15.2 \\
\hline M06 & 2 & 1739 & 14900 & 350 & 135. & 15.2 \\
\hline Average & - & 1644 & 14089 & 559 & 133 & 14.6 \\
\hline
\end{tabular}

- Has additional section containing family room and master bedroom

The manufactured home heating system consists of a furnace installed in a louvered cabinet inside the home. There is no ducted return system, although some furnaces receive ducted outside air through passive or active make-up air systems; metal trunk ducts on each side of the home are connected by a large-diameter flex duct (the cross-over duct). This duct runs from the bottom of the furnace supply plenum and reconnects to the trunk duct on the other side of the house. Depending upon the type of floor in the home, there can also be some small additional amount of ductwork running from the trunk ducts up to the supply register boots. The trunk. ducts and boots are constructed of 18-gauge aluminum, and are fabricated on-site. The floor is built up on top of a steel undercarriage with three levels of R-11 insulation placed on top of the undercarriage. The wooden floor joists are framed on top of this blanket. Additional insulation is then placed in the outermost parts of the floor joists, extending from the rim joists inward to the center of the floor for a distance of approximately four feet (see the Appendices for a floor schematic.)

The ducts are wrapped with R-5 insulation and run above the R-33 insulation in the belly; thus the ducts are in a buffer zone which is considerably warmer than a crawl space. Underneath the entire floor structure there is a continuous nylon barrier called the belly board which protects the insulation and framing members. Several plumbing lines penetrate this barrier; holes in the barrier may or may not be repaired after the home is transported and set up. 
The remainder of the house is insulated to standards equivalent to Pacific Northwest site-built codes, namely, R-21 walls with insulated headers and minimized framing lumber, R-38 vaulted ceilings or R-49 attics. The windows used perform on average to a U-value of 0.40 or better, and overall glazing area averages about $12 \%$ of the heated floor area.

Five homes in this field test were sited in western Washington, and thus were all in a climate zone with approximately 5000 Heating Degree Days (base $65^{\circ} \mathrm{F}$ ). This was done because of time and budget constraints and convenience of scheduling. The sixth home, site M01, was sited at an elevation of $1750 \mathrm{ft}^{3}$ just east of the Cascade crest. Efficiency loss findings can be applied to other climate zones easily with the use of simulation programs such as SUNDAYTM. Three of these homes were equipped with a ducted make-up air system into the furnace. Earlier measurements conducted by Ecotope have found that these 5 " to 7 " round ducts supply about 30 CFM to manufactured homes when the furnace is running. These units were disabled during our tests; therefore, no conclusions were made regarding their effective added ventilation to the building or their effect on pressurizing or depressurizing the building. 


\section{Air Leakage Results}

This section discusses leakage measurements of both the entire house (ducts included) and ducts by themselves. Table 2a presents the results of standard blower door tests. The house was depressurized to approximately $50 \mathrm{~Pa}$ relative to outside, with the ducts open to the house. The leakage of the entire system is expressed in cubic feet per minute (CFM). The values are directly measured and are not corrected for density changes due to altitude or for the temperature difference between the inside and outside. There is quite a bit of variation in this measure, with an average of 901 CFM and a standard deviation of about $30 \%$ of the mean.

TABLE 2A: HOUSE AIR LEAKAGE SUMMARY

\begin{tabular}{|c|c|c|c|c|c|c|c|c|}
\hline \multirow[b]{2}{*}{ Site ID } & \multicolumn{2}{|c|}{ Blower Door } & \multicolumn{4}{|c|}{ Tracer Decay ${ }^{3}$} & \multicolumn{2}{|c|}{$\Delta$ Pressure $[\mathrm{Pa}]$} \\
\hline & $\begin{array}{c}\mathrm{Q50}^{\mathrm{I}} \\
{[\mathrm{CFM}]}\end{array}$ & $\begin{array}{l}\mathrm{ACH}^{2} 50 \\
{[\mathrm{vol} / \mathrm{hr}]} \\
\end{array}$ & Fan Off & Fan On & Difference & $\begin{array}{l}\text { Exhaust } \\
\text { Fans }\end{array}$ & Envelope $^{5}$ & $\begin{array}{c}\text { Bedroom } \\
\text { Door }^{6}\end{array}$ \\
\hline M01 & 504 & 4.00 & 0.10 & 0.22 & 0.12 & 0.58 & 0.8 & 9.4 \\
\hline M02 & 1257 & 5.17 & 0.16 & 0.20 & 0.04 & 0.40 & 0.4 & 2.0 \\
\hline M03 & 989 & 3.20 & 0.18 & 0.28 & 0.10 & & 0.4 & 4.6 \\
\hline M04 & 840 & 3.40 & 0.16 & 0.16 & 0.00 & & 0.8 & \\
\hline M05 & 766 & 3.25 & 0.10 & 0.13 & 0.03 & 0.76 & 0.5 & 5.8 \\
\hline M06 & 1050 & 4.23 & 0.07 & 0.13 & 0.06 & & 0.3 & 3.0 \\
\hline Average & 901 & 3.88 & 0.13 & 0.19 & 0.06 & 0.58 & 0.5 & 5.0 \\
\hline $\begin{array}{l}\text { Standard } \\
\text { Deviation }\end{array}$ & 259 & 0.76 & 0.04 & 0.06 & 0.04 & 0.18 & 0.2 & 2.9 \\
\hline
\end{tabular}

1 Total leakage in $\mathrm{ft}^{3} / \mathrm{min}$ with ducts unsealed and house depressurized to $50 \mathrm{~Pa}$. Furnace and exhaust fans off.

2 Same conditions as above but leakage expressed in air changes per hour.

3 Total leakage expressed in air changes per hour based on tracer gas decay test.

4 Both bathroom ventilation fans on. Air handler fan off. Due to time constraints this test was not performed at every site.

3 Change in pressure across house envelope due to air handler fan (fan on - fan off). In all cases the houses are depressurized with respect to outside. (Numbers shown are the absolute value of the $\Delta P$.)

- Change in pressure across the master bedroom door due to air handler (fan on - fan off). In all cases the bedrooms are pressurized with respect to the main part of the house. Most master bedrooms have over-door fixed-blade louvers.

7 Interior doors were not yet installed at this site.

The next measure is the air exchange rate at $50 \mathrm{~Pa}$, which is obtained by normalizing the $\mathrm{CFM}$ rate by the house volume. These homes average an air exchange rate of 3.88 , which is very tight by any standard applied to site-built or manufactured homes. The Bonneville Power 
TABLE 2B: COMPARATIVE WHOLE-HOUSE LEAKAGE RATES

\begin{tabular}{|l|c|c|l|l|c|}
\hline \multicolumn{1}{|c|}{ STUDY } & $\begin{array}{c}\text { 'Energy } \\
\text { Efficient } \\
\text { Homes"' }\end{array}$ & $\begin{array}{c}\text { NUMBER } \\
\text { OF } \\
\text { HOMES }\end{array}$ & $\begin{array}{c}\text { HOUSE } \\
\text { TYPE }\end{array}$ & $\begin{array}{l}\text {.YEAR } \\
\text { BUILT }\end{array}$ & ACH 50 \\
\hline $\begin{array}{l}\text { Palmiter \& Brown } \\
\text { (1989) }\end{array}$ & No & 134 & Site-built & $1980-86$ & 9.28 \\
\hline Palmiter et. al. (1990a) & Yes & 49 & Site-built & $1987-88$ & 7.18 \\
\hline Palmiter et. al. (1990b) & Yes & 129 & Site-built & 1989 & 5.55 \\
\hline Kennedy et. al. (1994) & No & 21 & Manufactured & $1965-80$ & 14.3 \\
\hline Palmiter et. al. (1992) & No & 29 & Manufactured & late 1980s & 8.75 \\
\hline Palmiter et. al. (1992) & Yes & 131 & Manufactured & late 1980s & 6.10 \\
\hline Davis \& Siegel (1994) & Yes & 150 & Manufactured & $1991-92$ & 5.50 \\
\hline
\end{tabular}

Affirmative entry means these homes were built to a more energy efficient standard than the most common practice at the time.

$\mathrm{ACH}_{50}$ is a useful comparison measurement; however, houses very rarely experience pressure gradients of $50 \mathrm{~Pa}$. Therefore, we also performed tracer gas tests to estimate the effective with the furnace air handler fan on and off. ${ }^{2}$ The tracer gas decay test was performed by injecting sulfur hexafluoride $\left(\mathrm{SF}_{2}\right)$ into the home's air handler until the concentration reached about $5 \mathrm{ppm}$. The air handler fan was left on, (mixing fans were placed in all rooms to circulate the air) and the concentration was allowed to drop by approximately $10 \%$. The air handler fan was then turned off. The gas concentration was allowed to drop by an additional $10 \%$. The house air change rate for both cases was determined from the slope of a linear regression of the concentration versus time. A Bruel and Kjaer 1303 gas analyzer was used to measure the $\mathrm{SF}_{6}$ concentration.

Table $2 \mathrm{a}$ shows the results of the decay tests with the air handler fan on and off. With the fan off (natural infiltration), the average air change rate was 0.13 , ranging from a low of 0.07 to a high of 0.18 . With the fan on, the air change rate increased on average to 0.19 , ranging from 0.13 (Sites M05 and M06) up to 0.28 (Site M03). In these cases, none of the houses meet the ASHRAE standard 62 minimum effective ventilation rate of 0.35 air changes (ASHRAE, 1989). The difference between fan-on and fan-off house air change rate reflects the effects of duct leakage and added infiltration when the fan is running, and range from 0.004 (Site M04) to 0.12 (Site M01). The average of the differences between fan-on and fan-off with the tracer gas averaged only $6 / 100$ of an air change.

\footnotetext{
${ }^{2}$ The effective ventilation rate is the rate at which pollutants leave the home and are, replaced with outside air. This rate is controlled mostly by stack effect in the Pacific Northwest. The effective ventilation rate is almost always less than the average ventilation rate (which is customarily used for heat loss calculations). The two rates are sometimes confused and used interchangeably.
} 
We also made tracer measurements of the exhaust fan flow through the houses. The average ACH with the fan on was 0.4 ; though this average is above the ASHRAE Standard 62 minimum effective ventilation rate, the exhaust fans ran an average of 8 hours per day in the houses that we tested. Therefore, daily effective ventilation rate is still considerably below the minimum ASHRAE standard.

The make-up air systems for these homes were disabled for all tests because no reliable procedure has been developed to describe their contribution to overall heating system efficiency and house tightness. During normal furnace operation the make-up air duct behaves like and intentional return leak. Unpublished field measurements by Ecotope suggest a make-up system contribution of between 30 and 50 CFM during fumace operation if the duct is not obstructed by a jammed or inoperative damper. During some times of the day, the make-up system acts as a natural stack vent. When exhaust fans are operating and the furnace air handler is off, the location of neutral pressure line cannot always be determined, and air flow direction is also difficult to establish. Further research should be conducted on the magnitude of the make-up air system on the effective ventilation rate of manufactured homes.

For the purpose of estimating the combined effect of unintentional leaks and exhaust fan operation, we can take a weighted average of the tracer decay air change rates for the natural leakage case ("Furnace Fan Off" in Table 2a) and the three exhaust fan on cases ("Exhaust Fans" in Table 2a). The tracer decay test is, again, a measure of effective ventilation rate and therefore describes how quickly pollutants are removed from the home's interior. Note that there are only three pairs of data for which this can be done (sites M01, M02, and M05).

For an average exhaust fan run-time of eight hours per day, the weighted average effective ventilation rate for the three hours in $0.29 \mathrm{ACH}$. While much closer to the ASHRAE Standard 62 than the average natural effective ventilation rate of $0.13 \mathrm{ACH}$, the fan-assisted ventilation rate still fails the standard. Given evidence from the other work (Davis \& Siegel, 1994) of variable exhaust fan run times, very tight building envelopes, and questionable fan longevity, alternative ventilation. strategies should be designed and tested.

As has been noted before, tracer decay tests are likely to be biased low. All decay tests assume that complete mixing of the tracer occurs, and that none of the air entering the house and duct system from outside has any tracer in it. We believe that this may not be true, and that some air entering the house contains tracer gas in concentrations above the background concentration. Air enters the house from the ducts may also contain tracer gas. Both fan-on and fan-off tests are probably biased low. The first tracer test introduces gas into the crawil space and belly area when the air handler is on, and some of this-air must remain in the crawl space and belly, only to reenter the house during the fan-off tests. This means that the air change rates measured with a tracer decay are appropriate for air quality concerns, but they are biased low for purposes of evaluating efficiency impacts of heat loss due to infiltration.

In addition to the duct leakage bias problem, tracer gas measurements can be influenced by variations in wind speed and the temperature difference between inside the home and outside. Tests generally took three hours to complete, so the conditions during the fan-on test were not necessarily the same as those during fan-off. During this testing. we noticed that the gas monitor 
occasionally exhibited erratic behavior, however, the regressions of concentration versus time displayed very high correlations.

Table $2 \mathrm{a}$ also shows the measurement of the pressure change across the envelope of the house when the air handler is turned on. This measurement averaged $-0.5 \mathrm{~Pa}$ for this set of houses, indicating that the house was slightly depressurized when the air handler was running versus when the air handler was off. This is not unexpected, since there is no return system in the house other than that provided by the air handler cabinet. There are no return systems running in exterior spaces which could bring in extra air via leaks to pressurize the house. A pressure difference of zero across the envelope with the air handler running would indicate that either there were no return leaks at all or that supply and return leaks were balanced. This relatively small net depressurization when the air handler is running is not as troubling as the much larger values found in site-built homes, where it was not uncommon to find a $+/-2.0 \mathrm{~Pa}$ gradient due to air handler operation (Olson, et al., 1993).

Table $2 \mathrm{a}$ also shows the average of the absolute values of pressures measured across interior doors when closed one by one. Previous studies of infiltration in electrically heated homes . (Palmiter and Bond, 1991) show that the closing of even a single bedroom door can more than double the infiltration in the rest of the house. We ran all of our efficiency tests with all interior doors open, and no adjustment to the system efficiency was made to account for door closures. The pressurization of rooms with doors closed is somewhat offset by the installation of over-door or ceiling pass-through ventilation louvers. The air flow through these louvers has been measured by Ecotope and is usually only 5 to $10 \mathrm{CFM}$; pressure differences on the order of $3 \mathrm{~Pa}$ still exist between louvered master bedroom suites and the rest of the house when the master bedroom door is closed.

Table $2 c$ summarizes statistics that have attracted considerable attention (and controversy) in recent energy conservation field testing. These are duct leakage measurements made directly with the Minneapolis Duct Blaster ${ }^{\mathrm{TM}}$. The leakage rates measured at a duct system pressure of 25 $\mathrm{Pa}$ and $50 \mathrm{~Pa}$ are reported here. These measurements were taken by sealing the houses' supply registers and replacing the air handler fan with the Duct Blaster ${ }^{\mathrm{TM}}$ fan, then pressurizing the system to a point near these two pressures. The duct pressure was measured with a Pitot tube placed in the supply plenum. 
TABLE 2C: DUCT AIR LEAKAGE SUMMARY

\begin{tabular}{|c|c|c|c|c|c|c|}
\hline Site ID & $\begin{array}{c}\text { Total } \\
\text { Leakage } \\
\text { at } 50 \mathrm{~Pa} \\
{[\mathrm{CFM}]}\end{array}$ & $\begin{array}{l}\text { Exterior } \\
\text { Leakage } \\
\text { at } 50 \mathrm{~Pa} \\
{[\mathrm{CFM}] .}\end{array}$ & $\begin{array}{c}\text { Exterior } \\
\text { Leakage } \\
\text { at } 50 \mathrm{~Pa} \text { as a \% } \\
\text { of total at } 50 \mathrm{~Pa}\end{array}$ & $\begin{array}{c}\text { Total. } \\
\text { Leakage } \\
\text { at } 25 \mathrm{~Pa} \\
{[\mathrm{CFM}]} \\
\end{array}$ & $\begin{array}{l}\text { Exterior } \\
\text { Leakage } \\
\text { at } 25 \mathrm{~Pa} \\
{[\mathrm{CFM}]} \\
\end{array}$ & $\begin{array}{c}\text { Exterior } \\
\text { Leakage } \\
\text { at } 25 \mathrm{~Pa} \text { as a } \% \\
\text { of total at } 25 \mathrm{~Pa}\end{array}$ \\
\hline MO1 & 118 & 51 & 43 & 76. & 36 & 47 \\
\hline $\mathrm{M} 02$ & 179 & 126 & 70 & 117 & 86. & 74 \\
\hline M03 & 232 & 122 & 53 & 150 & 96 & 64 \\
\hline M04 & 122 & 34 & 28 & 77 & 24 & 31 \\
\hline M05 & 201 & 105 & 52 & 123 & 67 & 5.4 \\
\hline M06 & 158 & 82 & 52 & 102 & 54 & 53 \\
\hline Average & 168 & 87 & 50 & 107 & 60 & 54 \\
\hline Std. Deviation & 41 & 35 & 14 & 26 & 26 & 15 \\
\hline
\end{tabular}

Total duct leakage is reported at both $25 \mathrm{~Pa}$ and $50 \mathrm{~Pa}$. We also measure exterior duct leakage. There is some uncertainty in the validity of the exterior leakage measure, as it involves more a complicated test. In this procedure, a blower door pressurizes the house while the Duct Blaster ${ }^{\mathrm{TM}}$ is running and the pressure difference between the house and the ducts is brought to zero. Since we are only measuring the pressure difference between house and ducts at one point, it could be argued that at different points in the duct system one would obtain a non-zero pressure difference. However, this is the test that is routinely used in this kind of research, and the exterior leakage numbers found in this report were collected using this test.

The average exterior duct leak at $50 \mathrm{~Pa}$ is $87 \mathrm{CFM}$, with the standard deviation at almost half the mean. Site M01, with truck ducts made of fiberglass duct board rather than sheet metal and the smallest floor area $\left(960 \mathrm{ft}^{2}\right)$, and Site M04, with a longitudinal floor, had the lowest duct leakage to outside. Exterior leakage at $25 \mathrm{~Pa}$ averaged $60 \mathrm{CFM}$. This is a better estimate of actual exterior leakage, since $25 \mathrm{~Pa}$ is close to the average static pressure measured in these homes when the furnace is operating normally.

For both the $25 \mathrm{~Pa}$ and the $50 \mathrm{~Pa}$ duct leakage tests, the average exterior leakage is about half of the total leakage. This suggests, at least at the level, of first approximation, that roughly half of the heated air in the ducts finds its way back into the interior of the home through unintentional leaks. In practice, it is also very difficult to seal completely during field test. Supply registers and the air handler cabinet during the total duct leakage test some portion of the total leakage is therefore "false leakage." Thus, the exterior leakage measurements are more satisfactory descriptions of actual duct leakage. 


\section{Heating System Efficiency}

Conduction losses and air leakage from ducts are the main contributors to decreased heating efficiency. Conduction losses are a significant factor in heating system efficiency, since heating ducts are usually at temperatures considerably higher than their surroundings.

The second main cause of decreased efficiency, duct air leakage to or from the crawl space, has received a great deal of attention during recent testing seasons. The invention of the Minneapolis Duct Blaster ${ }^{T M}$, has enabled a direct measurement of total leakage. Total leakage includes leakage from the ducts back into the house around supply register boots, and leaks through holes into the belly area (which are assumed to also go into the crawl space). The Duct Blaster ${ }^{\mathrm{TM}}$ also provides an estimate of air leakage to the outside (as opposed to leakage coming back into the house). However, this measurement (done in combination with a blower door which pressurizes the house relative to outside) is still somewhat uncertain, as it assumes that the pressure gradient between the house and the duct system can be reduced to zero. This measurement of exterior leakage is further complicated by the nylon belly board, which acts as a partial air barrier (if it is not damaged during set-up).

Two independent standard measures of heating efficiency were used in the analysis: These, efficiency measures can be found in Chapter 29 of the 1992 ASHRAE HVAC Systems and Equipment Handbook (ASHRAE, 1992). The first measure is the heat delivery efficiency, which is defined as the total useful heat delivered to the supply registers while the fan is on, divided by the power input to the furnace (including fan power). The total useful heat delivered is determined by measuring the temperature and flow at supply registers, while the power input to the furnace was obtained from true power meters connected to the houses' electrical mains. This measure of efficiency does not take into account any supply leaks back to the home, nor any heat recovered from the ducts when the air handler fan is off. It also does not take into account the conduction and radiation of heat back into the home from the floor's structural members.

The second measure (and our main focus) was system efficiency. System efficiency is defined as the total useful heat delivered to the conditioned space during the entire period of furnace cycling, divided by the power input to the furnace (including fan power). "Total useful heat" as used here refers to the power that electric baseboards would use, (with ducts in place and open to the conditioned space, but with the furnace off) to maintain the same indoor temperatures as those provided by the furnace during normal cycling. Our protocol replaces these baseboards with portable electric heaters. We control the room temperatures by using an automated system which measures average temperatures during furnace cycling, and then uses these temperatures to turn the portable heaters off and on as needed to maintain the room temperature at the average measured temperature during furnace cycling. The furnace and portable heaters (co-heaters). were alternated on two-hour cycles. Electrical usage during these alternating periods was measured by true power meters on the electrical mains. Room and supply register temperatures are measured with Type $T$ thermocouple wires.

Power measurements cannot always be $100 \%$ accurate during the transition periods from co-heat to furnace heating modes, due to short-term thermal mass effects. The furnace will stay on 
longer at a transition to heat the duct and floor space that may have cooled off during the co-heat period. Conversely, the first part of the co-heating energy cycle consumes less than later on in the cycle. This is because the furnace has been cycling and has "overheated" the thermal mass slightly, reducing the heating load. For purposes of calculating system efficiency, we compared the second hour of the fumace and co-heat periods.

TABLE 3A: HEATING EFFICIENCIES

\begin{tabular}{|c|c|c|c|}
\hline Site ID & $\begin{array}{c}\text { System } \\
\text { Efficiency } \\
{[\%]} \\
\end{array}$ & $\begin{array}{c}\text { Heat Delivery } \\
\text { Efficiency } \\
{[\%]} \\
\end{array}$ & $\begin{array}{c}\text { Heat Recovery } \\
\text { Fraction }^{3}\end{array}$ \\
\hline MO1 & 83 & 64 & 0.53 \\
\hline M02 & 89 & 74 & 0.58 \\
\hline M03 & 81 & 67 & 0.42 \\
\hline M04 & 87 & 85 & 0.13 \\
\hline M05 & 74 & 61 & 0.33 \\
\hline M06 & 92 & 71 & 0.72 \\
\hline Average & 84 & 70 & 0.45 \\
\hline Standard Deviation & 6 & 9 & 0.25 \\
\hline
\end{tabular}

I System efficiency is the total heat delivered to the-conditioned space divided by the energy output of the heating system, as measured by the coheat method.

2 This efficiency is the heat delivered to the home though supply registers during the time the air handler fan is running divided by the energy output of the heating system. It does not account for factors such as supply leaks to the conditioned space, heat recovered from ducts during the off-cycle, or heat recovered from buffer zones.

3 (System efficiency - heat delivery efficiency)/( 1 - the heat delivery efficiency).

As Table 3 a shows, heat delivery efficiency varied substantially from house to house, with a low of $61 \%$ at Site M05 and a high of $85 \%$ at Site M04. Site M05 appeared to have some sort of blockage in the crossover duct that we could not positively identify, even on a return visit. The flows in one side of this home were much lower than the flows in the other side. Site M04 had a longitudinal floor, and therefore had less duct length and separation of ducts from the conditioned space. Almost all of the energy delivered to the air stream at the furnace finds its way into the conditioned space as useful heat. This duct runs very near the sub-floor, and a flow splitter is used at the furnace. This results in more even air flow in all supply registers in the home.

The efficiency number we are most interested in is system efficiency. The average system efficiency is $85 \%$. If Site MO5 is excluded, the average system efficiency is $86 \%$. This adjusted . average system efficiency is considerably higher than. what was found in Ecotope's study of 24 site-built homes (Olson, et al., 1993). In that study, the average adjusted system efficiency was 
71\%. The site-built homes had ducted return systems as well as supply systems; however, return leaks do not contribute as dramatically to system efficiency losses as do supply leaks. Supply leaks, because they involve higher temperature and pressure gradients, contribute disproportionately to the system efficiency loss.

A major goal of this heating system investigation was to test the efficiency numbers used in the MAP Technical Reference Manual (Davis and Baylon, 1992). The Reference Manual based its analysis on a combination of heat balance equations and a duct leakage rate based on one field test. In the analysis which follows, we suggest that conduction losses play a larger role in overall heating system efficiency than was assumed during the Reference Manual's preparation. The analysis inputs average temperature measurements during furnace cycling (Table 3B) with measurements of duct system pressures and flows (Table $3 \mathrm{C}$ ) into a duct modeled developed by Palmiter and Bond (1991b). This model enables an estimation of separate effects of duct air leakage and conduction loss on heating system efficiency.

Table 3B shows average temperatures measured with thermocouples during furnace cycling. The fourth column, the calculated temperature rise across the furnace, is included because of the difficulties in obtaining reliable supply plenum temperature measurements. This temperature rise is calculated directly from the air handler flow (Table $3 \mathrm{C}$ ) and the furnace fan-on power (Táble $4 \mathrm{~A})$.

\section{TABLE 3B: TEMPERATURES DURING FURNACE CYCLING}

\begin{tabular}{lccccc}
\hline Site ID & $\begin{array}{c}\text { Average } \\
\text { Room }\end{array}$ & $\begin{array}{c}\text { Average } \\
\text { Crawl }\end{array}$ & $\Delta$ Outside $^{1}$ & $\begin{array}{c}\text { Calc. Rise } \\
\text { Across Furnace }\end{array}$ & $\begin{array}{c}\text { Meas. Rise } \\
\text { Across } \\
\text { Furnace }^{3}\end{array}$ \\
\hline & & & & & \\
M01 & 75.6 & 48.2 & 31.5 & 54.3 & 41.1 \\
M02 & 76.3 & 46.6 & 35.6 & 56.3 & 49.0 \\
M03 & 74.8 & 47.5 & 29.2 & 44.1 & 41.4 \\
M04 & 74.1 & 44.1 & 40.7 & 37.7 & 42.6 \\
M05 & 75.7 & 48.4 & 33.3 & 56.2 & 48.3 \\
M06 & 74.1 & $* 4$ & 25.7 & 33.0 & 41.7 \\
& & & & 4 & \\
Average & $\mathbf{7 5 . 1}$ & $\mathbf{4 6 . 9}$ & $\mathbf{3 2 . 7}$ & $\mathbf{4 6 . 9}$ & $\mathbf{4 4 . 0}$ \\
Std. Deviation & $\mathbf{0 . 9}$ & $\mathbf{1 . 8}$ & $\mathbf{5 . 2}$ & $\mathbf{1 0 . 2}$ & $\mathbf{3 . 6}$ \\
\hline
\end{tabular}

Average room temperature minus average outside temperature.

Based on the AH fan flow and furnace fan-on power.

Average supply plenum temperature minus average return plenum pressure when the AH fan is on.

No crawl temperature was measured for site M04. There was no skirting around the perimeter of the house.

On a subsequent visit the crawl temperature was on average approximately $1^{\circ} \mathrm{F}$ warmer than the outside

temperature during furnace cycling. 
Table $3 \mathrm{C}$ summarizes air handler and supply register measurements. The first column shows the : static pressure in the supply plenum, as measured with a Pitot tube inserted into the plenum. This measurement is sometimes difficult to determine accurately, as in Site M01.

\section{TABLE 3C: HEATING SYSTEM FLOWS \& PRESSURES}

\begin{tabular}{|c|c|c|c|c|c|}
\hline Site ID & 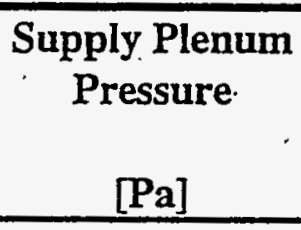 & $\begin{array}{c}\text { Sum of } \\
\text { Register } \\
\text { Flows } \\
\text { [CFM] }\end{array}$ & $\begin{array}{c}\text { AH Fan Flow } \\
{ }^{2} \\
\text { CFM }]^{3} \\
\end{array}$ & $\begin{array}{l}\text { Calculated Duct } \\
\text { Leakage (CDL) }\end{array}$ & $\begin{array}{l}\text { CDL as a \% } \\
\text { of AH flow } \\
\text { - }\end{array}$ \\
\hline M01 & 17.0 & 732 & 748 & 16 & 2.1 \\
\hline M02 & 21.1 & 715 & 761 & 46 & 6.0 \\
\hline M03 & 34.0 & 955 & 1016 & 61 & 6.0 \\
\hline M04 & 26.5 & 948 & 962 & 14 & 1.5 \\
\hline M05 & 27.0 & 621 & 666 & 45 & 6.8 \\
\hline M06 & 25.5 & 600 & 634 & 34 & 5.4 \\
\hline Average & 25.2 & 762 & .798 & 36 & 4.6 \\
\hline Standard & 5.8 & 155 & 157 & 18 & 2.2 \\
\hline Deviation & & & & & \\
\hline
\end{tabular}

1 As measured with the Lambert FH250 Flow Hood.

2 Register flows plus the calculated exterior duct leakage

3 Exterior duct leakage calculated at one haif the supply plenum static pressure.

4 Calculated duct leakage divided by air handler flow.

An accurate measurement of the air handler flow is necessary for calculating the air leakage from the duct system as a percentage of the air handler flow. This fraction is used as an input in estimating the part of the system efficiency loss which is due to air leakage.

To provide a better estimate of furnace air handler fan flow, we have employed an approach suggested by Mark Modera at Lawrence Berkeley Laboratory. He argues that the average static pressure in the duct system is the average of that found at the supply registers (effectively 0 ) and the static pressure measured at the supply plenum. The exterior duct leakage at this average pressure (which is half the supply plenum pressure) is found using the basic flow equation, $\mathrm{Q}=$ $\mathrm{Cp}^{\mathrm{n}}$, where $\mathbf{C}$ known from the two point exterior duct leakage test and $\mathbf{n}$ is assumed to equal 0.65 . This calculated leakage is then added to the sum of the supply register flows measured with the Lambert FH250 flow hood. These flows have been corrected for register air temperature and site altitude, to determine flows in standard CFM. We have cross-calibrated the 
Lambert with the Minneapolis Duct Blaster ${ }^{T M}$ and have found a high level of agreement ( $\pm 5 \%$ ) between these two measurement devices.

Table 3D shows the modeled results of combining the average temperatures measured during cycling with the calculated duct leakage as a percentage of the air handler flow. (The detailed equations for the model are found in the Appendix.) The efficiency loss due to duct air leakage alone is shown in the second column. The difference between this contributor and the overall system efficiency loss measured during the coheat test is shown in the third column.

TABLE 3D: MODELED DUCT EFFECTS ON EFFICIENCY

\begin{tabular}{lccc}
\hline Site ID & $\begin{array}{c}\text { Measured System } \\
\text { Efficiency Loss } \\
\text { (from coheat) }\end{array}$ & $\begin{array}{c}\text { Estimated System } \\
\text { Efficiency Loss } \\
\text { From Duct Air } \\
\text { Leakage }\end{array}$ & $\begin{array}{c}\text { Supposed Efficiency } \\
\text { Loss Due to } \\
\text { Conduction, Induced } \\
\text { Infiltration \& Other } \\
\text { Effects } \\
(\%)\end{array}$ \\
\hline M01 & $(\%)$ & $(\%)$ & 14.6 \\
M02 & 17 & 2.4 & 4.4 \\
M03 & 11 & 6.6 & 12.6 \\
M04 & 19 & 6.4 & 12.6 \\
M05 & 15 & 2.4 & 17.2 \\
M06 & 26 & 8.8 & 0.8 \\
Average & 8 & 7.2 & $10 . \dot{4}$ \\
\hline
\end{tabular}

The table suggests, if only coarsely, that duct air leakage is less a contributor to measured efficiency loss in these houses than may have been previously thought. Basing estimates of efficiency loss primarily on air leakage standards (which can, admittedly, be measured quickly in the plant or in the field) may not be as straightforward as some have suggested.

Several assumptions incorporated into the earlier analysis are now under review. (See the Appendix for a detailed account of this earlier analysis). Significantly, the supply duct leakage fraction used in the MAP Heat Loss Reference Manual (Davis and Baylon, 1992) measured as a percentage of air handler flow, was 3.5\%. The average supply leakage fraction measured in this study is $4.8 \%$. The efficiency loss measured in these six homes is at least two times larger than estimated before, with only a $37 \%$ increase in supply leakage fraction. This suggests, as shown in Table 3D, that conduction losses must be considered a greater contributor to efficiency loss. The crossover duct also was not explicitly modeled in the earlier work. The crossover duct has long been considered a weak link in manufactured homes heating systems, since it can be damaged easily during or after set-up. 
In summary, given the very low exterior duct leakage measured in this study, and given that there is still an average system efficiency loss of $14 \%$, more work must be done to understand contributors to efficiency loss and alternative design strategies. 


\section{Furnace Power Summary and Annual Heating Energy Impacts}

Table 4 a summarizes furnace power consumption and some measures of efficiency. This table is related to the system efficiency numbers discussed in Section 3. The heating system efficiencies from that section are used in this section to calculate absolute power loss and therefore more concretely describe the impact on heating energy.

TABLE 4A: FURNACE POWER SUMMARY

\begin{tabular}{|c|c|c|c|c|c|c|c|c|}
\hline Site ID & $\begin{array}{c}\text { Full } \\
\text { Power }^{1} \\
{[\mathrm{~W}]}\end{array}$ & $\begin{array}{c}\text { AH Fan } \\
\text { Power } \\
\text { [W] }\end{array}$ & $\begin{array}{c}\text { Fan-On } \\
\text { Power }^{2} \\
\text { [W] }\end{array}$ & $\begin{array}{l}\text { Fan-On } \\
\text { as \% of } \\
\text { Full }^{3}\end{array}$ & $\begin{array}{l}\text { Percent } \\
\text { Ontime }^{4}\end{array}$ & $\begin{array}{c}\text { Average } \\
\text { Cyc. Pwr } \\
{[\mathrm{W}]}\end{array}$ & $\frac{\text { Efficie }}{[\%]^{6}}$ & $\frac{\text { cy Loss }}{[W]^{7}}$ \\
\hline M01 & 11967 & 360 & 10727 & 83 & 16 & 1761 & 17 & 299 \\
\hline M02 & 15887 & 420 & 11909 & 74 & 33 & 3987. & 11 & 439 \\
\hline M03 & 20500 & 520 & 12430 & 60 & 33 & 4109 & 19 & 781 \\
\hline M04 & 12520 & 410 & 9983 & 81 & 50 & 5006 & 15 & 751 \\
\hline M05 & 15236 & 400 & 12197 & 79 & 29 & 3558 & 26 & 925 \\
\hline M06 & $8245^{8}$ & 400 & 7554 & 88 & 37 & 2773 & 8 & 222 \\
\hline Average & 14059 & 418 & 10800 & 77 & 33 & 3533 & 16 & 569 \\
\hline Std. Deviation & 4166 & 54 & 1846 & 10 & 11 & 1134 & 6 & 288 \\
\hline
\end{tabular}

Total power of all electric resistance elements and fan.

Average power consumption of elements and fan while fan is on during furnace cycle.

Ratio of fan-on power to full power as percent.

4 Percent of time the air handler was on during a complete furnace cycle.

s Fan-on power times percent on-time. This is the average power consumption during a complete furnace cycle.

6. 100 minus system efficiency.

Efficiency loss (\%) times average cycling power.

$\checkmark$ This furnace was on a dealer lot and was operated with only two heating elements connected.

The first number in the table is the full-power measurement, which is taken during the furnace warm-up test. In this test, the furnace is run continuously, long enough to level out the temperatures in the ducts; this number includes the fan power. The next column of the table is the fan-on power. This is the average power consumption of the furnace while the air handler fan is on, and is taken over all the furnace cycles used in the furnace efficiency analysis. This number is smaller than the measurement because of furnace elements sequencing. Electric furnaces have different elements that come on and go off at different times. Also, elements shut off before the fan goes off so that the fan can extract heat from the furnace cabinet and ducts according to its anticipator setting. Sequencing impacts system efficiency; efficiency decreases when elements 
first come on, because the average temperature of the return air is colder than when the furnace has just been turned off. The average inside house temperature is lower, and the depressurizing effect of the air handler fan brings in cold outside air through unintentional leaks and make-up air system. Some of the efficiency loss due to sequencing is recovered through the recapture of heated in the ducts after the air handler turns off. The last column in this table is the power loss, which is the product of efficiency loss and average cycling power. Power loss is the most important statistic in estimating the energy impacts of efficiency losses in manufactured homes. The average power loss of these homes is 459 watts, ranging from only 111 watts in Site M06 to 954 watts in Site M05. The power loss is a clearer method of expressing system efficiency losses than percentages. This is because different houses have different loads. Houses with large loads and small system efficiency losses can have larger power losses than houses with small loads and large system efficiency losses.

Table 4B uses the power loss as the basis for several statistics. The power loss is normalized by house size and also extended over a 120 day heating season to estimate the extra energy consumed and paid for as a result of duct effects. The average extra cost over a Pacific Northwest heating season of 120 days is about $\$ 80$.

TABLE 4B: NORMALIZED WATT LOSS

\begin{tabular}{|c|c|c|c|c|c|}
\hline Site ID & $\begin{array}{l}\text { Power Loss } \\
\text { (W) }\end{array}$ & $\begin{array}{c}\text { Home Size } \\
\left(\mathrm{ft}^{2}\right)\end{array}$ & Power Loss $/\left(\mathrm{ft}^{2}\right)$ & $\begin{array}{c}\text { Energy Loss per } \\
\text { Heating Season' } \\
(\mathrm{kWh})\end{array}$ & $\begin{array}{l}\text { Extra Cost per } \\
\text { Heating Season } \\
\text { (\$) }\end{array}$ \\
\hline M01 & 299 & 960 & 0.31 & 861 & 43 \\
\hline M02 & 439 & 1716 & 0.26 & 1264 & 63 \\
\hline M03 & 781 & 2038 & 0.38 & 2249 & 112 \\
\hline M04 & 751 & 1709 & 0.44 & 2162 & 108 \\
\hline M05 & 925 & 1699 & 0.54 & 2664 & 133 \\
\hline M06 & 222 & 1739 & 0.13 & 639 & 32 \\
\hline Average & 569 & 1644 & 0.34 & 1640 & 82 \\
\hline
\end{tabular}

Assumes 120 day heating season

Assumes electricity cost of $\$ 0.05 / \mathrm{kWh}$. 


\section{Summary of Findings}

This report presents the results of field measurements conducted on six manufactured homes in the Pacific Northwest. The purpose of the research was to estimate the effects of heating distribution systems on fumace efficiency and heating energy use in these homes. The research was not conducted on a large enough sample to draw definitive conclusions; however, it is an important preliminary effort towards understanding the operation of forced-air systems in manufactured homes built to Model Conservation Standards.

The adjusted average system efficiency as defined by ASHRAE (1992), including heat recovered from buffer spaces and bypasses, was $86 \%$. This means that these manufactured homes, constructed to energy standards equivalent to the 1991 Model Conservation Standards (MCS), use on average 1.16 times as much heating energy as they would if heated with electric baseboards. While a significant efficiency loss, this finding of system efficiency is considerably better than that found during a study of 24 site-built homes during the 1992 and 1993 heating seasons. That study found an average system efficiency loss of $29 \%$, but those homes had ducted return systems and much longer and leakier supply systems.

These houses were found to be very tight, with natural effective air change rates averaging only $0.13 \mathrm{ACH}$. This air change rate is much lower than the ASHRAE standard 62. Even with exhaust fan operation, the effective ventilation rate fails the standard. Alternative ventilation systems are needed for these homes.

Duct leakage is these homes was very small; averaging $4.6 \%$ of the furnace air handler flow. Duct air leakage may be much less of a contributor to system efficiency loss than conduction losses at such small leakage rates. More research must be conducted on the separate and combined contributions of the duct system effects to heating system efficiency loss. 


\section{References}

ASHRAE, 1992. HVAC Systems and Equipment Handbook. Atlanta: American Society of Heating, Refrigerating and Air-Conditioning Engineers, Inc.

Davis, B. and J. Siegel. 1994. "Field Study of 150 Manufactured Homes Constructed Under the Manufactured Homes Acquisition Program", work in progress for Bonneville Power Administration under Contract No. DE-AM79-91BP13330.

Davis, B. and D. Baylon. 1992. Manufactured Homes Acquisition Program: Heat Loss Assumptions and Calculations; Heat Loss. Coefficient Tables. Prepared for Bonneville Power Administration under Contract No. DEAM79-91BP13330.

Gilbertson, W.L., F. V. DiMassa, A. D. Lee, and S. A. Onisko. 1993. A Road Map for Süccess: How Northwest Manufactured Housing Conservation Efforts Revolutionized an Industry. Prepared for the Bonneville Power Administration under Contract No. DE-AC0676RLO1830.

Judkoff, R. and G. Barker. 1992. Thermal Testing of the HUD Energy Efficiency Standard for New'Manufactured Homes. Prepared by the National Renewable Energy Laboratory for the U.S. Department of Energy under Contract No. DE-AC02-83CH10093.

Kennedy, M., P. Francisco, J Heller, B. Manclark, and L. Palmiter. 1994. Energy Exchanger Installation Quality Assurance Study. Prepared for Washington Water Power Company under'Contract No. R-0166-93

Modera, M.P. 1989. "Residential Duct System Leakage: Magnitude, Impacts and Potential for Reduction". ASHRAE Transactions, 1989.

Olson, J., L. Palmiter, B. Davis, M. Geffon, and T. Bond. 1993. Field Measurements of the Heating Efficiency of Electric Forced-Air Systems in 24 Homes. Prepared for the Washington State Energy Office under Contract No. 90-05-12.

Palmiter, L., T. Bond, I. Brown, and D. Baylon. 1992. Measured Infiltration and Ventilation in Manufactured Homes. Prepared for Bonneville Power Administration under Contract No. DE-AM79-91BP 13330 .

Palmiter, L., I. Brown and T. Bond. 1991a. "Measured Infiltration and Ventilation in 472 AllElectric Homes". ASHRAE Transactions, 1991. Atlanta: American Society of Heating, Refrigerating and Air-Conditioning Engineers, Inc.

Palmiter, L. and T. Bond. 1991b. "Interaction of Mechanical Systems and Natural Infiltration." Presented at the AIVC Conference on Air Movement and Ventilation Control Within Buildings, Ottawa, Canada. 
Palmiter, L., I. Brown, and T. Bond. 1990a. Residential Construction Demonstration Project, Cycle II: Infiltration and Ventilation of New Electrically Manufactured Homes in the Pacific Northwest. Ecotope, Inc., Seattle

Palmiter, L., I. Brown, and T. Bond. 1990b. Northwest Residential Infiltration Study, Cycle II: Infiltration and Ventilation in New Electrically Heated Homes in the Pacific Northwest. Ecotope, Inc., Seattle.

Palmiter, L. and I. Brown. 1989. Northwest Residential Infiltration Study, Volume 1: Analysis and Results. Prepared for the Bonneville power Administration under Washington State Energy Office Subcontract No. 88-24-01.

Parker, D.S. 1989. "Evidence of Increased Levels. of Space Heat Consumption and Air Leakage Associated With Forced-Air Heating Systems in Houses in the Pacific Northwest". ASHRAE Transactions, June 1989.

Robison, D. H. and L. A. Lambert. 1988. "Field Investigations of Residential Duct Leakage". Prepared for the Oregon Department of Energy under Contract No. 90023. 


\section{Acknowledgments}

Grateful acknowledgment is made to many people who assisted in recruiting test homes, helped with protocol development, and reviewed the draft of this report.

Two manufactured home dealerships in Western Washington were very helpful in assisting in recruiting: Gregersen Homes (Scott and Barbara Gregersen) and Heritage Homes (Don Nelsen and Karen Russell). Don Nelsen deserves particular recognition, because he allowed us to test one home on his lot, as well as recruiting an additional test site. He was very helpful and interested in our research every step of the way.

Ron Sparkman of Moduline Industries provided easy access to test sites used for protocol development before the main project began. Recognition is due DeTrey Homes in Lacey, Washington for the use of one of their lot models.

Mark Wiser of Chelan County PUD assisted in recruiting one home in eastern Washington.

Mike Lubliner of WSEO assisted in protocol development and provided many useful suggestions throughout the project.

We would also like to acknowledge the participation of the five families who let us test their homes: the Hayden-White family of Graham, Washington, the Thomas family of Langley, Washington, the Bowles family of Othello, Washington, the Rowe family of Vashon Island, and the Mosher family of Snoqualmie, Washington. All of the home owners were very cooperative and we thank them.

Several personnel at Ecotope contributed to the production of this report: Jonathan Heller, David Baylon and Michael Geffon. Joseph Olson, former research scientist at Ecotope, provided critical technical support.

Ken Eklund of Idaho Department of Water Resources - Energy Division provided comments on the draft of this report. Allen Lee of Battelle - Pacific Northwest Labs made many detailed comments on the draft which proved very useful in producing the final report.

Mark Jackson of the Bonneville Power Administration managed the contract. 


\section{APPENDIX}

Brief Summary of Protocol Test

MAP Heating Protocol

Manufactured Homes Floor Thermal Analysis excerpted from MAP Technical Reference Manual (Davis and Baylon, 1992)

Duct Model Equations excerpted from Palmiter and Bond. (1991b) 


\section{BRIEF SUMMARY OF PROTOCOL TESTS}

This appendix details several different tests performed to evaluate the heating system efficiency. and related parameters. These include a thorough house audit, an alternating coheat test, a . furnace steady-state temperature test, tracer gas decay tests, a two-point blower door test, duct tester measurements, and other miscellaneous measurements. The protocol takes roughly 45 technician-hours over a two day period to complete. The fist day is taken up mostly with setting up the alternating coheat test (placing thermocouple wires and power meters, etc.). This test runs overnight under automated control. The next half-day is spent completing testing and removing the test equipment.

\section{House Audit}

We performed a detailed audit of the house and entire heating system prior to running the tests. . The audit included drawing a floor plan of the house, complete with elevations, from which we calculated the house volume. The heating system was described in detail, including furnace and air handler fan specifications, duct length and make-up air system. Trunk ducts.were checked with a mirror for crushing and crossover ducts were also inspected. Any peculiarities or flaws in the furnace or duct system were noted.

\section{Coheat Test}

This test is the method by which we obtain the overall heating system efficiency. This is defined as the ratio of the power required to heat the home (as ducted) by electric resistance baseboard heating to the furnace power used during normal cycling to provide the same average room temperatures. For the purposes of this test, portable space heaters were placed in every room that had a supply register, and the house was alternately heated with these heaters and with the furnace at two hour intervals. Individual rooms were maintained at the same temperature during space heater operation as during furnace cycling, thus allowing us to separate the furnace and space heater energy demands. This methodology accounts for all heat delivered to the living space, including heat recovered from the ducts and crawl space, as well as uneven loading of buffer zones.

The space heaters and furnace were controlled with Campbell 21X dataloggers, which were commanded by batch files from a laptop computer. The furnace was controlled to cycle between six and eight times per hour, and the space heaters maintained room temperatures to $\pm 0.25^{\circ} \mathrm{C}$ of those produced during the previous furnace period. Furnace and coheat power consumption was monitored with a pair of clamp-on true power meters attached to the house electrical mains. Temperatures were measured with copper-constant (Type T) thermocouple wires.

Supply register air temperatures and flows were also measured. The flows were corrected to standard air density and multiplied by the register temperatures to calculate the total useful heat delivered to the conditioned space during furnace cycling periods. The heat delivery efficiency was then calculated by dividing the heat delivered through the registers by the power consumed by the furnace. This efficiency was calculated for the same furnace cycling period as the heating system efficiency. 


\section{Tracer Decay Test}

The tracer decay tests serve two purposes: they quantify the infiltration rate of the home with the fan running and they provide a measure of the additional infiltration added by the furnace air handler fan. The test was performed by injecting a quantity of sulfur hexafluoride $\left(\mathrm{SF}_{6}\right)$ into the home and measuring concentrations with a Brüel \& Kjær 1302 gas monitor. The furnace air handler is used to initially mix the house air, and then small portable oscillating fans are used to mix air continually during the decay tests.

During the first part of the test the air handler fan was on. When the concentration had dropped by $10 \%$, the air handler was turned off and the second test was conducted, until an additional $10 \%$ of the $\mathrm{SF}_{6}$ left the building. The time constants of the two decays are the air handler fan induced air-change rate and the natural infiltration rate of the house plus ducts, respectively. For some houses, a tracer decay test was also performed with exhaust fans operating.

\section{Blower Door and Duct Tester Measurements}

Envelope leakage was measured with a depressurization blower door test at $50 \mathrm{~Pa}$ and $25 \mathrm{~Pa}$. Pressures were measured with a two channel digital micromanometer.

A duct tester was used to directly measure duct leakage. These tests were done with supply grilles blocked. With the duct tester, the duct system was pressurized to $50 \mathrm{~Pa}$ (as measured in the supply plenum), and the flow through the duct tester fan (hence through duct leaks) was calculated. The test was repeated with the house pressurized to $50 \mathrm{~Pa}$ in order to isolate and quantify duct leakage to outdoors. This test was repeated at $25 \mathrm{~Pa}$.

\section{Additional Measurements}

The pressures across closed bedroom doors were measured with the furnace on. This gives an indication of the magnitude of increased infiltration due to differential pressurization when interior doors are closed. Pressures across the house envelope were also measured with the furnace both on and off to give an idea of the heating system leakage balance. The duct tester was attached to the furnace cabinet and used to measure the flow through the air handler fan with the furnace at its normal operating static pressure. 
MAP HEATING SYSTEM PROTOCOL

Date(s) of Visit

Field technicians

Audit form filled out by

Occupant Information

Name

Address

City

State

Phone\#

Home

Work

\section{Occupant Questions}

Be sure to get the letter of agreement signed.

Do you have any paperwork on the furnace? (Get it from the homeowner. Take a copy or get the document itself, promising to send it back).

If the thermostat is digital, get the operations manual. (Important!)

Do you have floor plans for this home? May we borrow them, please?

How many people live in this home?

Have you noticed any odor or moisture problems?

What manual setbacks do you normally use?

During which seasons is the air handler operated continuously?

Do you know where your system filter is?

How often do you change it?

When was the last time you changed it?

Window vent customary settings 


\section{MAP HEATING SYSTEM PROTOCOL}

\section{Initial Diagnostics and Setup}

Synchronize technician watches, dataloggers and computers. Pressures across the envelope (reference house):

\begin{tabular}{|l|l|l|}
\hline Measurement Location & $\triangle \mathrm{P}$ AH Fan Off & $\triangle \mathrm{P}$ AH Fan On \\
\hline & & \\
\hline & & \\
\hline & & \\
\hline
\end{tabular}

\section{Sketches}

Draw a rough floor plan of each level of the home, noting locations of supplies, returns, air handler, and exhaust fans. For heat pumps, include location of outside unit and refrigerant lines.

Number each supply register with a different number.

Draw a rough elevation view of the home, noting the height of ceilings, cathedral peaks, etc.

Take pictures at the four main directions of the house. There should be shots looking toward and away from the home.

Take pictures of air handler and any noteworthy interior or exterior details.

Home Description - Exterior

Crawl space vents: Number open Number closed

Orientation of long axis of house

Local topography

Altitude

Describe shielding and terrain for each of the four main directions

Other notes 


\section{MAP HEATING SYSTEM PROTOCOL}

Site ID:

Home Description - Interior

Make/model

Floor Area

Volume

Floor type

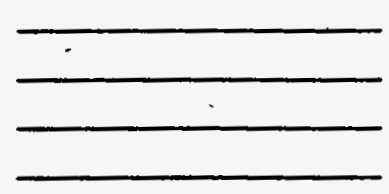

Number of bedrooms

Number of bathrooms

Number of other rooms

HUD \#S

Other notes

\section{Ventilation System}

Intake (include number, location and height of intake vents)

Exhaust

Controls (include humidistat or timer settings)

Makeup air system

Deactivate ventilation controls. Note disabling done:

Position of window vents 
MAP HEATING SYSTEM PROTOCOL

Site ID:

\section{Thermostat}

Thermostat location

Thermostat make and model

Fan-only switch

Yes

No

Anticipator setting

amps

Measure control circuit amperage:

1) Remove thermostat

2) Put Fluke ammeter between terminals $R$ and $W$ on sub-base

3) Let furnace run for one minute and read amperage

Set anticipator to amperage read

List all thermostat programs as found:

List programs as tested:

Quick Air Flow Measurement

1) Let the air handler run for 5 minutes.

2) Measure the supply temperature

3) Measure the return temperature

4) Measure the power through both hearing circuits with the power meter:

watts

5) If supply air temperature is greater than $140^{\circ} \mathrm{F}$ and airflow is low, check whether the air handler is cycling on the limit switch.

Air flow calculation:

$\Delta \mathrm{T}=$ Supply $\mathrm{T}=$ Return $\mathrm{T}=$

Watts/ $\Delta \mathrm{T}(\mathrm{F})) \times 3.16=$ SCFM

or

Watts/ $\Delta \mathrm{T}(\mathrm{C})) \times 1.75=$ SCFM. 


\section{MAP HEATING SYSTEM PROTOCOL}

\section{Heating System}

Flow type: Upflow Downflow ___ Sideflow

Locate breakers for furnace on each leg of the circuit. Note breaker amperage.

Nameplate Information

Record all information on all name plates (furnace, fan motor, electronic air cleaner, etc.)

Make and model

Maximum outlet temperature

Additional nameplate information:

Resistance heater make and model

Resistance heater power rating

Electronic air cleaner make and model

\section{Filters}

Describe filters .

(Number of filters, physical arrangement in air handler, etc.)

Filter condition

(Clean, OK, dirty, very dirty, impenetrable [inspect by holding up to light]) 


\section{MAP HEATING SYSTEM PROTOCOL}

\section{Page 6}

Site ID:
Air Handler Fan
From nameplate:
Blower make/model
Fan flow rating(s)
Fan power rating
Full loads amps

Measure fan motor with air handler cover plate closed by installing Sperry on furnace mains (or separate circuit for fan, if available).
Amps (rms)
Watts (rms)
Volts (rms)
Power factor

Number of taps connected to fan motor

If more than one tap is connected, determine whether the fan operates at different speeds with the heat on and off, and note below:

\section{Make-Up Air System}

From nameplate:

Blower make/model

Fan flow rating(s)

Measure flow under normal system operation with flow grid installed just above return side of system.
Fan pöwer rating Full loads amps.

Flow 


\section{MAP HEATING SYSTEM PROTOCOL}

\section{Air Handler Pressures}

Measure the pressures across the air handler cabinet with the fan running. Use the static pressure tap and measure through a crack in the air handler cabinet, through a hole created by removing a screw, or through a drilled hole. The positive side of the manometer should measure into the air handler. Measure with make-up air system enabled and disabled.

\begin{tabular}{|l|l|l|}
\hline & $\begin{array}{c}\text { Before filter } \\
\text { cleaning }\end{array}$ & $\begin{array}{c}\text { After filter } \\
\text { cleaning }\end{array}$ \\
\hline $\begin{array}{l}\text { Supply pressure with make-up air } \\
\text { system operating }\end{array}$ & & \\
\hline $\begin{array}{l}\text { Supply pressure with make-up air } \\
\text { system operating }\end{array}$ & & \\
\hline
\end{tabular}

\section{Cabinet and Plenums}

Description of furnace cabinet \& plenums (give dimensions):

Describe insulation in cabinet, if any:

Additional details: 


\section{MAP HEATING SYSTEM PROTOCOL}

\section{Site ID:}

\section{Supply Registers}

Position: Record the position of each register (open, partially open, closed). Open the register fully. Check the "restored" column when you have put the register back to its initial'position.

Flows: Measure supply flows with the air handler running with the heat on.

Measurement start time:

Measurement stop time:

\begin{tabular}{|c|c|c|c|c|c|}
\hline Register \# & Location & Position & $\begin{array}{c}\text { Flow hood } \\
\text { used }\end{array}$ & Flow (cfm) & Restored \\
\hline & - & & & & \\
\hline & & & 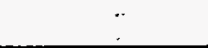 & & \\
\hline$\therefore$ & & & & & \\
\hline & & . & & & \\
\hline & & & & & \\
\hline & & & & & \\
\hline & & & & & \\
\hline & & & & & \\
\hline 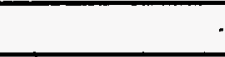 & & & & & \\
\hline & & & & & \\
\hline & & & & & \\
\hline & & & & & \\
\hline & & & & & \\
\hline & & & & & \\
\hline & & & & $\therefore$ & \\
\hline & & & & & \\
\hline & & & & & \\
\hline & & & & & \\
\hline & & & & & \\
\hline & & & & & \\
\hline & & & & & \\
\hline & & & & $\begin{array}{l}\text { Total } \\
\text { Flow }\end{array}$ & \\
\hline
\end{tabular}




\section{MAP HEATING SYSTEM PROTOCOL}

Site ID:

Page 9

\section{Ductwork}

Total ductwork footage

\section{Supply Ducts}

Pull off supply registers and inspect for cracks. Use a flashlight and a mirror. Notes:

Description of crossover duct connections (if accessible):

Other supply duct notes

\section{Pressures Across Bedroom Doors}

Measure pressures across bedroom doors (positive tap inside bedroom, negative outside). Only one interior door closed at a time!

\begin{tabular}{|l|l|l|l|}
\hline Room & P, AH off & P, AH on & Undercut \\
\hline & & & \\
\hline & & & \\
\hline & & & \\
\hline
\end{tabular}




\section{MAP HEATING SYSTEM PROTOCOL}

Site ID:

\section{Tracer Test}

Injection points:

Sampling points:

\section{Background}

Turn on $\mathrm{B} \& \mathrm{~K}$ and measure all six gases (with compensation for $\mathrm{H}_{2} \mathrm{O}$ ) for about one hour.

Time started

Time finished

\section{Decay}

Decay tests required are:

- Fan on

- Testing registers unsealed; fan off

Turn on $\mathrm{B} \& \mathrm{~K}$ and measure $\mathrm{SF}_{6}$ with compensation for $\mathrm{H}_{2} \mathrm{O}$.

\begin{tabular}{|c|c|c|l|}
\hline Time & $\begin{array}{c}\text { Conc } \\
(\mathrm{ppm})\end{array}$ & \multicolumn{1}{|c|}{$\Delta \mathrm{T}$} & \multicolumn{1}{|c|}{ Description \& Notes } \\
\hline & & & Start injecting, fan on \\
\hline & & & Stop injecting; leave fan on until concentration drops 10\% \\
\hline & & & Turn fan off \\
\hline & & & Wait until conc drops additional 10\% \\
\hline & & & End of test \\
\hline
\end{tabular}




\section{MAP HEATING SYSTEM PROTOCOL}

Site ID:

\section{Datalogger Setup}

Select temperature control zones and install thermocouples and coheaters. Put TCs in all registers, in the supply plenum, the furnace closet, and outdoors. Also measure temperatures in the crawlspace and belly blanket (center section and outrigger section).

List channels on each datalogger in the tables on this and the next page.

\section{Master Datalogger}

\begin{tabular}{|l|l|l|}
\hline Channel \# & TC\# & Description \\
\hline & & \\
\hline & & \\
\hline & & \\
\hline & & \\
\hline & & \\
\hline & & \\
\hline & & \\
\hline & & \\
\hline & & \\
\hline & & \\
\hline & & \\
\hline & & \\
\hline & & \\
\hline & & \\
\hline
\end{tabular}


Site ID:

\section{Slave Datalogger}

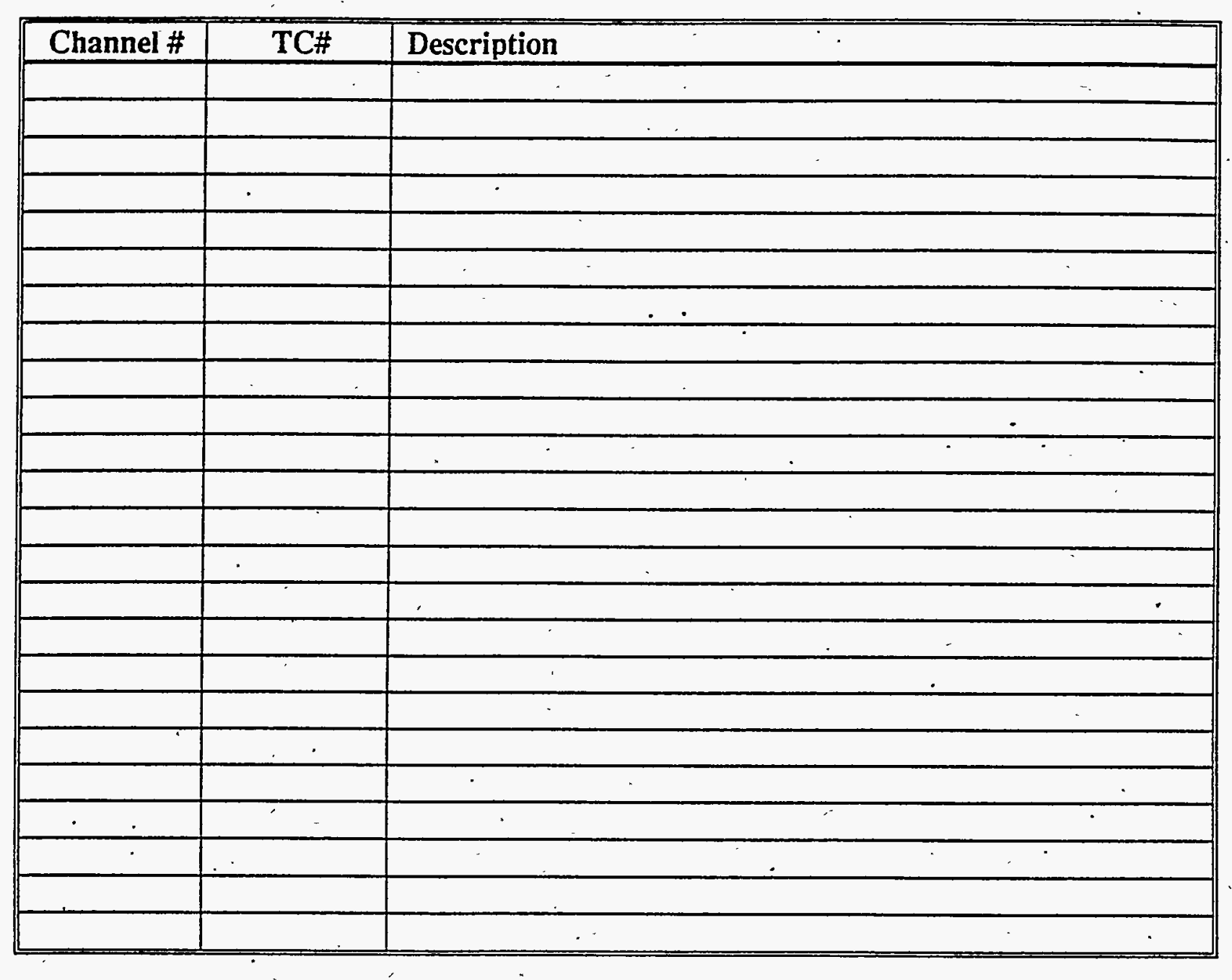




\section{MAP HEATING SYSTEM PROTOCOL}

Site ID:

\section{Furnace and Coheat Tests}

After running the LOAD program to set up the computer, and after all the equipment is set up, experiment with setting the setpoint and deadband.

Make sure all non-essential loads are disconnected: domestic hot water, refrigerator, make-up air, freezer, well, sump pump, and exterior lighting. When the furnace is cycling about six times per hour, start averaging zone temperatures. Make sure all coheaters come on and oscillate properly. Then load the HEATAG program, which will automatically run furnace and coheaters for alternating 2-hour periods throughout the night.

\begin{tabular}{|c|c|c|c|}
\hline Time & Setpoint. & Deadband & Furnace Cycles/Hour \\
\hline & & & \\
\hline & & & \\
\hline & & & \\
\hline
\end{tabular}

Coheat Control Points

\begin{tabular}{|c|c|c|c|c|c|}
\hline$\#$ & $\begin{array}{c}\text { TC } \\
\text { Location }\end{array}$ & $\begin{array}{c}\text { Control } \\
\text { Temp }\end{array}$ & $\begin{array}{c}\text { Heater Locations } \\
\text { (also see floorplan) }\end{array}$ & $\begin{array}{c}\text { Heater Settings } \\
\text { (W) }\end{array}$ & Notes \\
\hline & & & & & \\
\hline & & & & & \\
\hline & & & & & \\
\hline & & & & & \\
\hline & & & & & \\
\hline
\end{tabular}




\section{BLOWER DOOR AND DUCT BLASTER TESTS}

\section{1) BLOWER DOOR TEST}

Set-up: Close all windows and doors to the outside. Open all interior doors and close all dampers and doors on wood stoves and fireplaces. Make sure that furnace and water heater can not come on during test. Make sure all fans are off.

Reference Pressure

Plug fan hole and record pressure difference across the door.

Turn blower door on and depressurize house to $25 \mathrm{~Pa}$ from reference pressure.

Negative house pressure: Ring size $(O, A, B, C)$ : Flow pressure:

CFM:

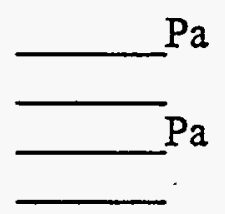

Turn blower door on and depressurize house to $50 \mathrm{~Pa}$ from reference pressure.

Negative house pressure: Ring size $(O, A, B, C)$ :

Flow pressure: $\mathrm{Pa}$

CFM:

\section{2) AIR HANDLER FLOW MEASUREMENT}

Set-up: All zones with duct work opened to outdoors and each other, where possible. Turn on air handler with fan switch.

Reference static supply pressure: (from Page 7)

Turn blower door (Duct Blaster off, no rings). If supply pressure is close to the original value, add Ring 1. Turn on Duct Blaster and slowly increase flow until supply pressure matches original value. Record Duct Blaster flow pressure and CFM.

Supply pressure: $\mathrm{Pa}$

Ring \#

Flow pressure: Table CFM: 


\section{MAP HEATING SYSTEM PROTOCOL}

\section{3)}

\section{SUPPLY AIR-LEAKAGE TEST}

Set-up: $\quad$ Return opening sealed in blower compartment

Duct Blaster attached to blower access opening as in Test 1

All zones open to outside or each other

All registers sealed with tape and paper

Remove blower from furnace (make sure breakers off) or fit cover over fan plenum and attach Duct Blaster.

\section{Total leakage (50 and 25)}

Pressurize supply system to about 50 Pascals, measure near supply plenum with smallest ring possible using the pressure tap previously installed. near 50 Pascals (use 10 second average)

Supply pressure

Ring \#

Flow pressure

CFM

Pressurize supply system to about 25 Pascals, measure near supply plenum with smallest ring possible near 25 Pascals (use 10 second average)

Supply pressure

Ring \#

Flow pressure

CFM 


\section{MAP HEATING SYSTEM PRÓTOCOL}

Site ID:

\section{Supply Air Leakage Test, con't.}

\section{Supply Leakage to outside (50 and 25)}

Set-up:

Blower door set to pressurize heated space

Internal doors of heated space open

Connections to outdoors from heated space closed

Set Duct Blaster for 50 Pascals in supply system

Set house to 50 Pascals

Adjust Duct Blaster to 50 Pascals

Final Adjustment: Adjust Duct Blaster or blower door so that delta-P between heated space and supply system near plenum is 0 . Record supply pressure outside. Repeat at 25 Pascals.

A) Pressurize house to about 50 Pascals, measure near supply plenum turn on Duct Blaster, increase speed until duct pressure is zero near 50 Pascals (use 10 second average).

Supply pressure

Ring \#

Flow pressure

CFM

Pressurize supply system to about 25 Pascals, measure near supply plenum turn on Duct Blaster, increase speed until duct pressure is zero near 25 Pascals (use 10 second average)

Supply pressure

Ring \#

Flow pressure

CFM 


\section{Manufactured Homes Floor Thermal Analysis}

\section{Component Analysis}

\subsection{Floor Systems}

\subsubsection{Construction Techniques}

Manufactured home floor systems differ from site-built home floors in two imporiant respects. First, the floor is framed on top of a steel undercarriage made of steel I-beams (which run the length of the home) and outriggers (placed several feet apart, which run from the outer I-beam to the perimeter of the home). This undercarriage is the means by which the structure is towed from the factory to the home site. In the most commonly found construction techniques, the crushing of insulation batts between the floor joists and the undercarriage reduces the performance of insulation. Second, heating system ducts run in the floor system. In most insulation strategies currently used, the ducts compromise the thermal pefformance of the floor system; however, the effect has been reduced a great deal in homes built to MAP specifications, where duct losses are confined to the area between the steel I-beams (transverse and upright transverse floors) or to one joist cavity (longitudinal floor). Drawings of these floors are found in the appendix.

Three floor system construction techniques are described here. The transverse floor, in which the floor is framed upside down and is perpendicular to the steel undercarriage, is the most common technique found in the Northwest. The second framing scheme, the upright transverse floor system, is similar but the floor is constructed upright. The longitudinal floor is framed so that the floor joists run parallel to the steel I-beams and are supported with steel stays which run orthogonally to the I-beams.

\section{Transverse Floor System}

Most Northwest manufacturers construct a floor structure which is called "transverse." In this configuration, $2 \times 6$ (or $2 \times 8$ ) floor joists are placed at right angles to the steel I-beams and parallel to steel ourriggers (which extend from the I-beams to the rim joists) that make up the undercarriage of the home. The floor is assembled upside down, with the heating ducts, plumbing lines, and electrical service located in the center ("belly") portion of the floor system. A "belly blanket" (one or more layers of insulation) is placed over the floor framing and the various utility conduits, then covered with a reinforced plastic sheet called the "belly board" (or "bottom board"). The steel undercarriage is placed on top of this layer and strapped and bolted to the joist assembly. The entire system is then flipped back over and the interior flooring and heating registers are installed.

The belly blanket insulation is brought up into the joist cavity in the outrigger region (the outer 3 feet of each side of the double-wide) by cutting the batts where they come up against the joists and pushing the batts into the joist cavity. This strategy reduces the compression which nomally occurs when the belly blanket is crushed between the steel undercarriage and the joists. (The compression is not totally reduced, because the bottom layer or layers of belly insulation are usually still crushed between the floor joists and l-beanus.)

The belly. blanket is crushed at the edges of the home and between the steel I-beams and the floor joists: Normal density joist insulation may be compressed depending on the framing depth and the insulation thickness. For example, an R-19 batt is usually 6 " thick. If an R-19 ball is placed in a $2 \times 6$ frame, where the cavity space is only 
5-1/2", compression reduces the performance of the insulation by $5.3 \%$. (See Table 3.) The R-21 high-density batt has an uncompressed thickness of $51 / 2^{\prime \prime}$, so it will retain full $R$-value in the $51 / 2^{\prime \prime}$ joist cavity.

Each half of a double-wide home's floor is thus constructed. The two halves are joined, and an insulated flexible crossover duct, which runs below the belly board, connects the two supply ducts in each half.

Duct conductive losses and the infiltration/exfiltration they induce affect the performance of floor insulation. The effect of duct leakage on the floor U-factor is taken into account in the U-factor calculation. Duct insulation improves the floor system's themal performance. Duct insulation is assumed to be a full R-5 insulation wrap around the duct.

\section{Upright Transverse Floor System}

The upright transverse floor is framed similarly to the more common transverse floor, except the floor is framed on top of the undercarriage, rather than the other way around. This presents some problems, since the insulation drapes over the undercarriage prior to the framing.

Typically, the belly blanket insulation is laid on top of the belly board before framing the ends. Then the space between the joists is insulated with insulation that extends across the floor structure and under the supply duct. Since the belly blanket is continuous across the floor, additional layers are placed in the center section of the steel undercarriage (between the I-beams) before the duct is placed in the frame. Then, the floor framing is put in place, compressing the belly blanket at the steel carriage. A partial layer of insulation is placed in the floor cavity space from above before the flooring is installed. This last layer of insulation is cut so that the insulation does not extend over the duct but falls down into the cavity space above the belly blanket. It is important to ensure that the joist insulation not.cover the duct at all, thereby minimizing the effect of duct losses on the floor's insulation performance.

\section{Longitudinal Floor System}

In the longitudinal configuration, the floor structure is constructed similarly to the transverse floor, however, the floor joists are placed parallel to the steel undercarriage I-beams. Each heating duct is located inside one joist cavity (rather than being strapped to the bottom of the joists and perpendicular to them).

In this case the floor is framed upright, similar to the upright transverse floor. The belly blanket is draped over the steel carriage and framing is placed on top of the belly blanket, compressing it. The joist cavities are insulated individually, with the insulation supported by the steel structure below. In the center a single joist cavity is given over to the duct. The thermal performance of this floor improves due to the amount of insulation that can be installed below the duct. 


\subsubsection{Thermal Analysis}

To analyze thermal performance of floor systems in manufactured homes, we used a one-dimensional heat loss analysis, adjusted to account for two important factors. The first of these is the compression (and subsequent reduction in performance) of belly blanket and joist insulation: The second is the interaction between the heating system ducts and the floor system insulation.

The first step in finding a $U$-factor for a given insulation value is to calculate a "steady-state" conductance of the floor system. This calculation takes into account the compression of insulation in the belly blanket and (if applicable) in the joist cavities. The framing correction is also made in this step. For homes with zonal heating (baseboard units or wall heaters), this value is in fact the floor U-factor. The next step is to adjust the U-factor so that the effects of duct losses are inciuded. Ducts affect floor insulation performance by pressurizing some of the floor assembly and by compromising the effectiveness of joist insulation which might be placed above the duct. (The second effect is not an issue in floors built to MAP specifications, since no joist insulation is placed above the duct region.) The buffering effect of the crawlspace is taken into account in this step.

\section{Insulation Compression and Conductance}

The belly blanket conductance varies due to compression of the insulation. There are several distinct compression regions for the belly blanket, each corresponding to an area of the floor, and each with a different conductance. Belly blanket insulation is compressed between the belly board and the underside of the joists in the ourrigger region, between the I-beams and the joists, and between the belly board and the bottom of the heating duct (in some cases).

The compression for different insulation configurations was determined from site visits and some simplifications were made (for example, assuming a uniform slope of the insulation in compression zones, as shown in the following figure). Figure 1 shows the compression regions with corrected $R$-values for an $R-33$ transverse floor. This figure extends from the rim joist (at left) to the other side of one half of a double-wide home.

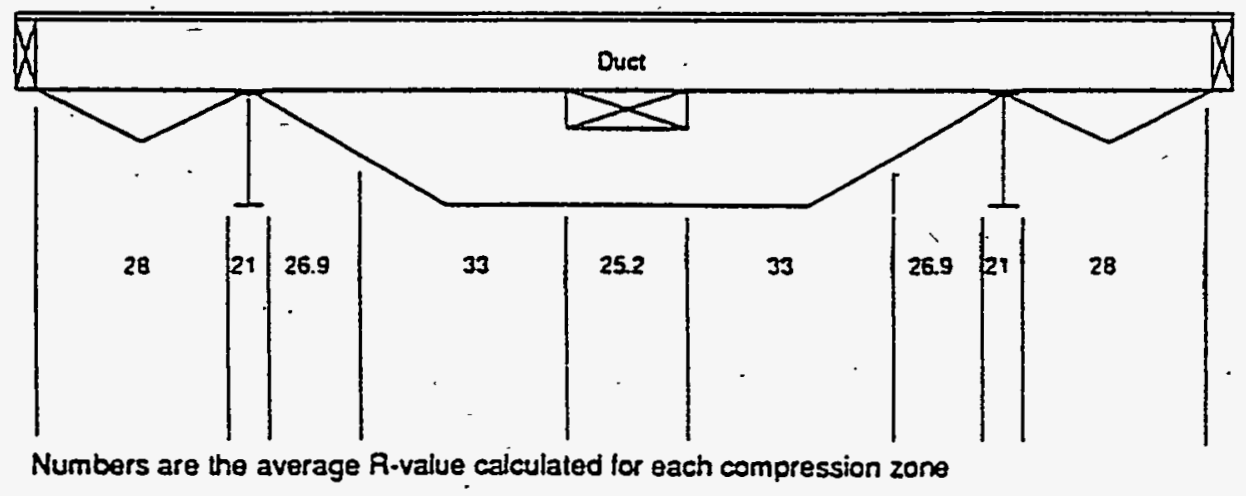

Figure 1. Insulation Compression Regions, R-33 Transverse Floor System 
In cases where the compression in the region was less than or equal to $50 \%$ of the nominal thickness of the batt or batts, Equation 1 (Section 2.1.2) was used to find an $\mathrm{R}$-yalue. In cases where compression exceeds $50 \%$ (where insulation is crushed between joist and I-beam, for example), information from manufacturers (Manville, 1988 ) was used to estimate the R-value.

$R$-values were calculated for the joist and belly regions in each compression zone. These values were weighted by the zone's square footage and summed. The reciprocals of the values for joist and belly regions, the so-called "steady-state" $U$-factors, were input into the duct model (described below) to calculate an overall floor system U-factor. For homes without forced-air systems, the steady-state floor U-factors should be used.

\section{Effect of Forced Air Furnace and Ducts on Floor Performance}

System supply ducts located in the belly cavity (between the floor joists and the belly. blanket) complicate the calculation of the floor U-factor. The ducts conduct heat and leak conditioned air into this cavity. The belly cavity behaves like a buffer space and the total floor-to-buffer and buffer-to-ambient conductivities must be added in series (after correction for insulation compression, described above) to get the overall floor system U-factor.'

We define the buffer in a transverse and upright transverse floor as the space where air moves freely between the lower edge of the joists and the belly blanket. For transverse and upright transverse floors, the buffer was considered to be restricted to the area between the I-beams if there is enough thickness of insulation in the joist space to completely fill the space. An R-22 cransverse floor would meet this condition, as the nominal thickness of the R-22 is $7^{\prime \prime}$ and the available joist space is only $5.5^{\prime \prime}$ if $2 \times 6$ floor joists are used. (The belly board also compresses the insulation by more than 1.5" in some parts of the outrigger region.) If the joist space is not full, duct losses will pressurize more:of the floor system and the floor U-factor will increase. In longitudinal floors, because the duct runs inside one joist cavity, the buffer is confined to the cavity in which the duct is located.

We calculated an overall floor conductivity (U-factor) for various insulation strategies. These U-factors were further adjusted to include duct insulation. To determine floor U-factors, we used a special version of the SUNDAY simulation program. The progrum combines SUNDAY with an equipment model developed for use in WATTSUN 5.0. The full model explanation can be found in Kennedy (1991), but a brief description follows.

SUNDAY is used to calculate the building load for a typical year. The equipment model then calculates the duct load and equipment energy needed to meet the building load. The model estimates a duct space temperature (in this case, the belly cavity temperature) and duct temperature, which are then used to calculate duct conduction loss and to adjust the floor loss. The effective conductivity of the belly region is this adjusted floor loss, normalized by the house-to-ambient temperature difference and the belly cavity area (square footage).

Inputs necessary for the duct model are the conductivity of the supply duct, the conductivity of the house-to-belly cavity interface and the belly cavity-to-ambient interface, the belly cavity area, and the leakage fraction of the supply ducts. The fumace on-time is also needed. It is found in an earlier part of the model through an iterative solution which is bused on building heating load and furnace capacity. 
The supply duct conductivity is calculated based upon the duct area and the presence of insulation. Heat loss from the bottom of the duct is ignored in this calculation since it presses directly into the belly insulation and does not contribute heat into the belly cavity. The conductivity used for bare metal duct is $1 \mathrm{Btu} / \mathrm{hr}-\mathrm{ft}^{2}-\mathrm{F}$; the conductivity for a metal duct with $\mathrm{R}-5$ insulation is $0.25 \mathrm{Btu} / \mathrm{hr}-\mathrm{ft}^{2}-\mathrm{F}$. The duct insulation conductivity is an estimate and is considered roughly the same for duct insulation between $R-4$ and $R-7$. For the higher $R$-values, insulation compression will reduce the actual $R$-value of the insulation. We chose $R-5$ as the most likely average $R$-value of duct insulation and used a $U$-factor $(0.25)$ which is even more conservative to account for compression.

The calculated conductive duct heat loss (UA) for longitudinal floors is significantly reduced from that for transverse floors because the hearing risers make up considerably less length in longitudinal floors.

We use a supply duct leakage fraction of 3.5 percent of the air handler flow. This value was derived from detailed constant-injection tracer gas measurements of a manufactured home (Palmiter \& Bond, 1991). This value may vary, depending on duct sealing techniques and flow configuration. In the absence of further data, the quality of duct sealing must be emphasized. Careful application of high quality sealants and metal duct tape at register boots and duct ends is key to minimizing duct losses and consequent degradation of floor thermal performance.

Table 6 shows the extent to which the performance of floor systems is reduced by the effects of a forced air furnace and ducts. The numbers listed (called "heating system efficiency factors") are the ratio between the yearly building load without heating system effects and the load with induced infiltration and conduction losses from the heating system and ducts included.

The table can be used to compare homes with forced air furnaces to those without. A home's steady-state UA can be divided by the appropriate furnace efficiency factor to calculate a corrected UA which includes heating system and duct effects.

\begin{tabular}{|c|c|c|c|c|}
\hline \multicolumn{5}{|c|}{ Heating System Efficiency Factors } \\
\hline floor type & $\begin{array}{c}\text { nominal belly } \\
\text { insulation, }\end{array}$ & $\begin{array}{c}\text { nominal } \\
\text { joist ins. }\end{array}$ & $\begin{array}{c}\text { w/uninsu- } \\
\text { lated ducts }\end{array}$ & $\begin{array}{c}\text { w/R-5 } \\
\text { duct } \\
\text { wrap }\end{array}$ \\
\hline & $\because$ & R- value & Htg Sys. & Factor \\
\hline \multirow{2}{*}{ transverse } & 22 & -- & 0.92 & 0.95 \\
\cline { 2 - 5 } & 3.3 & -- & 0.93 & 0.95 \\
\cline { 2 - 5 } & 44 & -- & 0.94 & 0.95 \\
\hline \hline $\begin{array}{c}\text { upright } \\
\text { transverse }\end{array}$ & 11 & 22 & -- & 0.96 \\
\hline \hline $\begin{array}{c}\text { longi- } \\
\text { tudinal }\end{array}$ & all cases & & 0.96 & 0.96 \\
\hline
\end{tabular}




\section{FLOOR SYSTEMS}




\section{Transverse Floor System}

In this floor configuration, the $2 \times 6$ (or $2 \times 8$ ) floor joists are placed at right angles to the steel I-beams and parallel to steel outriggers (which extend from the I-beams to the rim joists) that make up the undercarriage of the home. The floor is assembled upside down, with the heating ducts, plumbing lines, and electrical service located in the center ("belly") portion of the floor system. A "belly blanket" (one or more layers of insulation) is placed over the floor framing and. the various utility conduits, then covered with a reinforced plastic sheet called the "belly board" (or "bottom board"). The steel undercarriage is placed on top of this layer and strapped and bolted to the joist assembly. The entire system is then flipped back over and the flooring and heating registers installed.

Each half of a double-wide home's floor is thus constructed. The two halves are joined, and an insulated flexible crossover duct, which runs below the belly board, connects the supply ducts in each half to each other.

The belly blanket is brought up into the joist cavity in the outrigger region. (the outer three feet of each side of the home) by cutting the batts where they come up against the joists and pulling the batts into the joist cavity. This strategy eliminates or greatly reduces (depending on the amount of insulation used) the "sandwich" effect in the transverse floor, where the batts are crushed between the I-beams and floor joists.

The belly blanket is still compressed somewhat in the outrigger region and much more where the I-beams and floor joists attach. (See the depiction of the R-33 floor on the next page). Some compression also occurs between the bottom of the duct and the belly board.

In the cavity at the end of each trailer, the insulation should be cut into the last cavity or a batt of similar R-value added at the joist cavity between the I-beams or vertically between the flooring and the belly blanket insulation.

Two types of U-factors are found in the table in this section. A "steady-state" U-factor is listed for homes with zonal heating (baseboard units and wall heaters). For houses with forced air heating systems, duct conductive losses and the infiltration/exfiltration they induce affect the performance of floor system insulation. These effects must be taken into account when calculating the floor system U-factor for homes with forced air heating systems. (See Section 3.1.2 for further discussion.) The $U$-factors in the two right columns of the table include duct losses. 


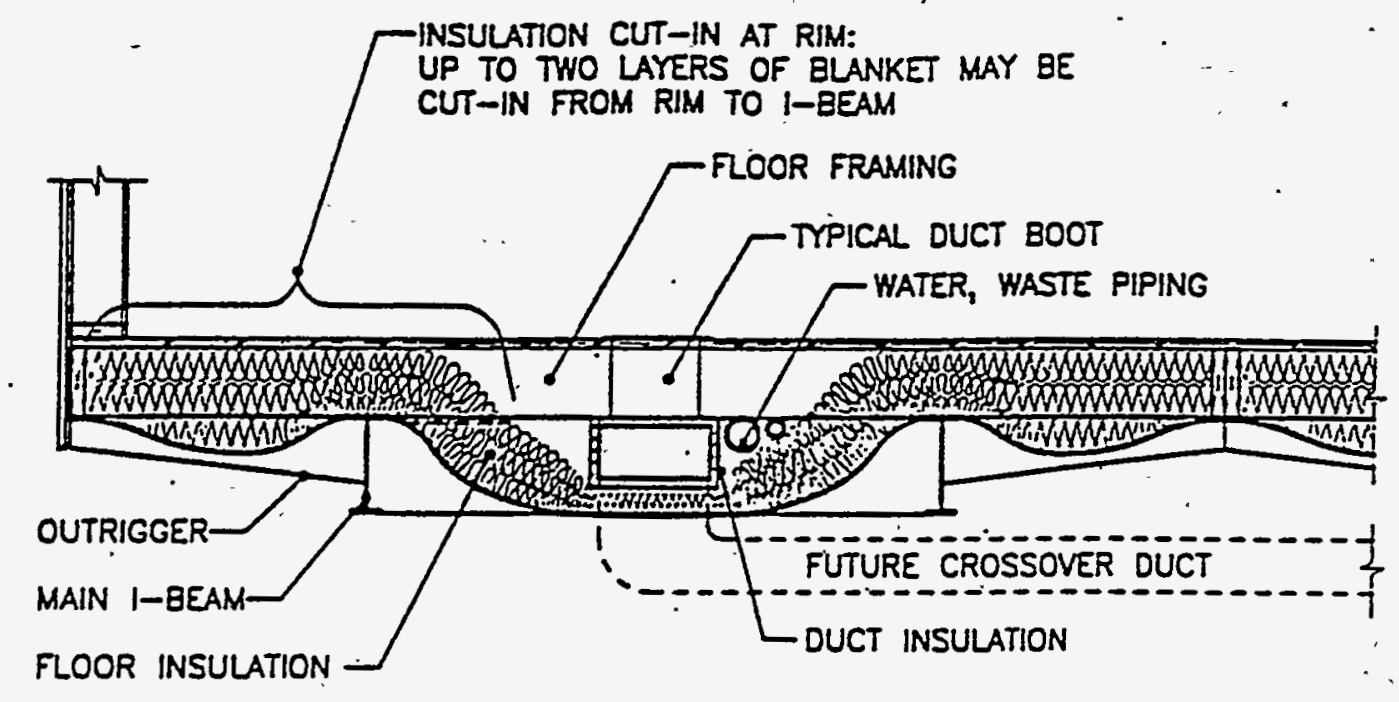

\begin{tabular}{|c|c|c|c|c|}
\hline \multicolumn{5}{|c|}{ 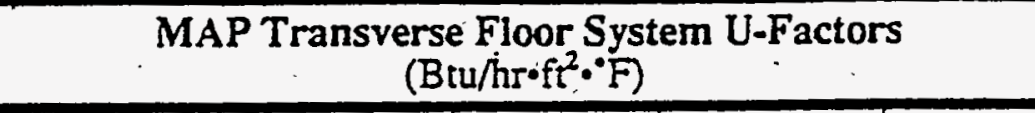 } \\
\hline $\begin{array}{c}\text { nominal belly } \\
\text { insulation } \\
\text { (R-value) }\end{array}$ & $\begin{array}{l}\text { fioor } \\
\text { framing }\end{array}$ & $\begin{array}{l}\text { steady } \\
\text { state (no } \\
\text { duct } \\
\text { effects } \\
\text { included) }\end{array}$ & $\begin{array}{l}\text { ducts with } \\
\text { R-5 wrap }\end{array}$ & $\begin{array}{l}\text { unin- } \\
\text { sulated } \\
\text { ducts }\end{array}$ \\
\hline 33. & $2 \times 6$ & 0.032 & 0.033 & 0.035 \\
\hline 33 & $2 \times 8$ & 0.031 & 0.032 & 0.034 \\
\hline 44 & $2 \times 6$ & 0.030 & 0.031 & 0.032 \\
\hline 44 & $2 \times 8$ & 0.029 & 0.030 & 0.031 \\
\hline
\end{tabular}

\begin{tabular}{|c|c|c|c|c|}
\hline \multicolumn{5}{|c|}{$\begin{array}{l}\text { Additional Transverse Fioor System U-Factors } \\
\left(\mathrm{Btu} / \mathrm{hr} \cdot \mathrm{ft}^{2} \bullet^{\circ} \mathrm{F}\right)\end{array}$} \\
\hline $\begin{array}{l}\text { nominal belly } \\
\text { insulation } \\
\text { (R-value) }\end{array}$ & $\begin{array}{c}\text { floor } \\
\text { framing }\end{array}$ & $\begin{array}{l}\text { steady. } \\
\text { state (no } \\
\text { duct } \\
\text { effects } \\
\text { included) }\end{array}$ & $\begin{array}{l}\text { ducts with } \\
\text { R-5 wrap }\end{array}$ & $\begin{array}{l}\text { unin- } \\
\text { sulated } \\
\text { ducts }\end{array}$ \\
\hline 11 & $2 \times 6$ & 0.066 & 0.070 & $0: 075$ \\
\hline 19 & $2 \times 6$ & 0.048 & 0.050 & 0.054 \\
\hline 22 & $2 \times 6$ & 0.044 & 0.046 & 0.049 \\
\hline
\end{tabular}




\section{Upright Transverse Floor System}

The upright transverse floor system is similar to the transverse floor system except that it is framed upright on the steel undercarriage. As a result the cut-in technology used for conventionally-framed transverse floors cannot be used. The belly board and belly blanket are draped over the steel undercarriage. The duct is put in place along with electrical and plumbing services and then the framing is placed over the top, crushing the belly blanket and allowing insulation to be placed in from the top.

The general strategy is to increase the amount of belly insulation between the two steel I-beams and to install shortened batts in the joist space which extend from the rim joist to about 6 inches from the edge of the duct. (See first drawing on next page.) Since the insulation is placed in from above, more conventional batt insulation can be used with depth depending on the size of the floor joists themselves.

The analysis procedure used for this floor system is essentially the same as that used for the conventional transverse floor. Duct behavior is similar. Some improvement in performance is possible, given the extra insulation installed between the steel carriage I-beam and the duct. Duct insulation, as with all other floor systems, improves the performance of the floor. We used R-5 duct insulation in the calculations.

It is very important to use enough insulation between the rim joist and the I-beam so that air movement from the duct region to the rim joist is minimized. 'An extra piece of $R-11$ is added in two of the $2 \times 8$ floors to do this; the batt should extend at least l' from the rim joist toward the center of the floor. (See second drawing on next page.)

The rim joist at the end of each trailer must also be insulated. If the duct extends to the outer wall, a R-19 or R-21 insulation batt should be placed vertically between the flooring and the belly blanket insulation, between the I-beams. If the duct stops short of the outside wall, then regular floor joist insulation should be placed in the last joist cavity next to the end wall.

For the last listing in the table, R-30 is used as the joist insulation, with this full value extending to within 6 " of the duct (as described above).

\begin{tabular}{|c|c|c|c|c|}
\hline \multicolumn{5}{|c|}{$\begin{array}{l}\text { Upright Transverse Flour System U-Factors } \\
\left(B t u / h r \cdot f^{2} \cdot{ }^{2}\right)\end{array}$} \\
\hline $\begin{array}{l}\text { nominal bclly/joist } \\
\text { insulation } \\
\text { (R-valuc) }\end{array}$ & $\begin{array}{l}\text { floor } \\
\text { framing }\end{array}$ & $\begin{array}{l}\text { steady state } \\
\text { (no duct } \\
\text { cffects } \\
\text { included) }\end{array}$ & $\begin{array}{l}\text { ducts with } \\
\text { R-5 wrap }\end{array}$ & $\begin{array}{l}\text { unin- } \\
\text { sulated } \\
\text { ducts }\end{array}$ \\
\hline $33^{\circ} / 19$ & $2 \times 6$ & 0.028 & 0.029 & .0 .030 \\
\hline $33 / 19+11(0)^{\cdots}$ & $2 \times 8$ & 0.028 & 0.029 & 0.030 \\
\hline $33 / 21^{*}$ & $2 \times 6$ & 0.026 & 0.027 & 0.028 \\
\hline $33 / 22$ & $2 \times 6$ & 0.027 & 0.028 & 0.029 \\
\hline $33 / 21+11(0)^{\cdots \infty}$ & $2 \times 8$ & 0.027 & 0.028 & 0.030 \\
\hline $33 / 22+11(0)$ & $2 \times 8$ & 0.028 & 0.029 & 0.030 \\
\hline $33 / 30$ & $2 \times 8$ & 0.024 & 0.025 & 0.026 \\
\hline
\end{tabular}

- R-11 belly blanket throughout, with udditional R-22 under duct region (sec first drawing on ncx! pagc)

* R-21 joist insulation is high density fibcrglass $\left(51 / 2^{*}\right.$ thick)

**= Extra R-11 batt extending from outrigger (o) at least l' toward center of floor (sce second drawing on next pagc) . 

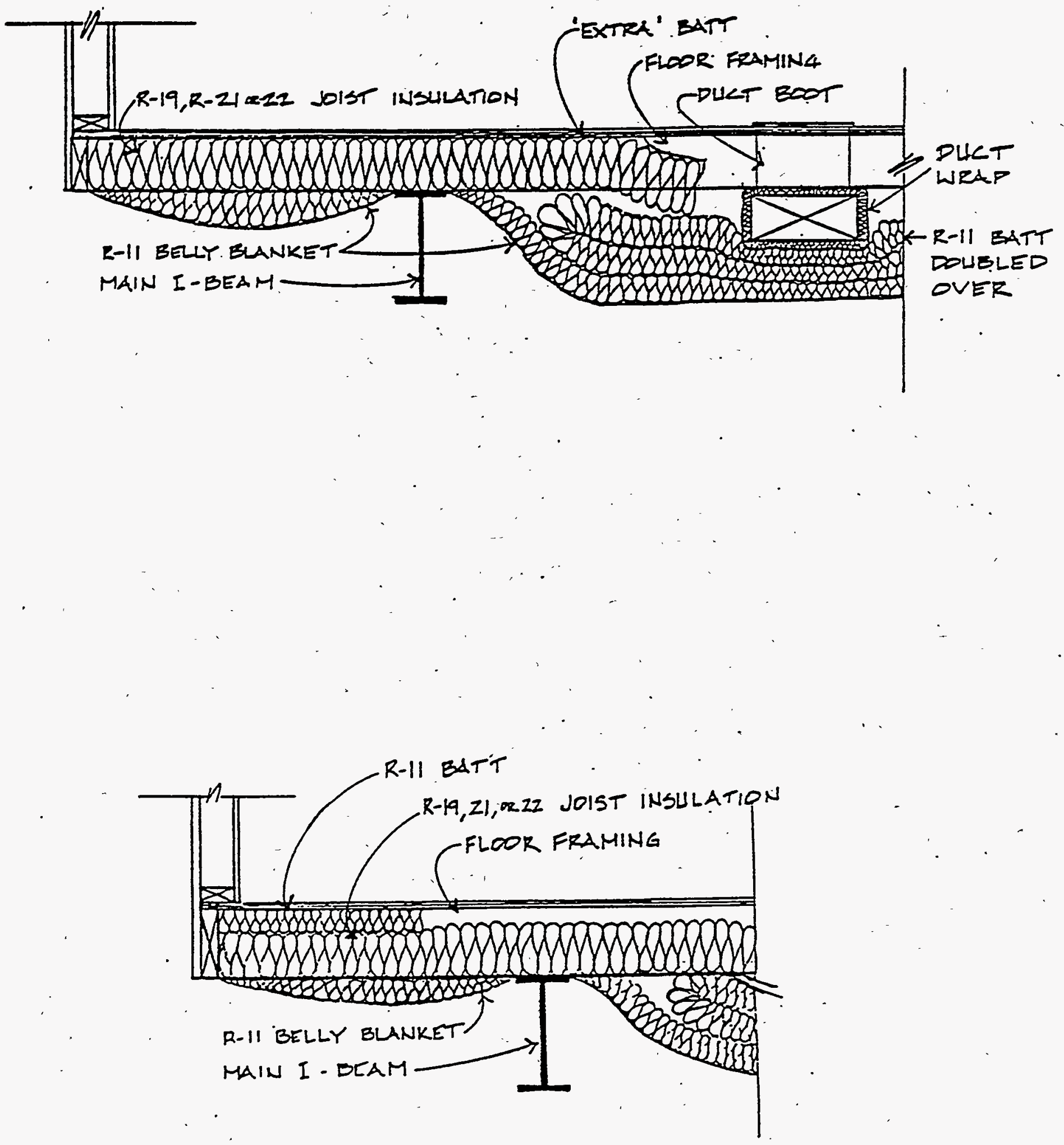


\section{Longitudinal Floor System}

In the longitudinal floor configuration, the floor is constructed in a way that is similar to the transverse floor, however, the $2 \times 6$ floor joists are placed parallel to the steel undercarriage I-beams. The heating ducts, plumbing lines, and electrical service are located inside joist cavities in the center portion of the floor.

The floor is assembled upside down. First, the wooden floor frame is nailed together. The utility . conduits (electrical and plumbing lines, heating ducts) are installed, then a "belly blanket" (one or more layers of insulation) is rolled over the assembly and covered with a reinforced plastic sheet called the "belly board" (or "bottom board"). The steel undercarriage is placed on top of all of this and surapped and bolted to the joist assembly. The entire system is then flipped. back over and the flooring and heating registers installed.

Each half of a double-wide home's floor is thus constructed. The two halves are joined, and an insulated flexible crossover duct, which runs below the belly board, connects the supply duct in each half.

Depending on the manufacturer, various levels of insulation are used in the belly blanket and joist cavities. The belly blanket is compressed somewhat in the region between the outermost I-beam and the rim joists and crushed dramatically where the I-beams and floor joists cross. Joist cavity insulation is compressed if it is R-19 or R-22, since the cavity space is only $51 / 2 . "$ This compression reduces the performance of the insulation and was taken into account when computing the overall floor U-factor. The high-density R-21 batt fits into the $51 / 2$ " space with no compression.

Two types of U-factors are found in the table in this section. A "steady-state" U-factor is listed for homes with zonal heating (baseboard units and wall heaters). For houses with forced air heating systems, duct conductive losses and the infiltration/exfiltration they induce affect the performance of floor system inșulation. These effects must be taken into account when calculating the floor system U-factor for homes with forced air hearing systems. (See Section 3.1.2 for further discussion.) The U-factors in the three right columns (calculated for uninsulated ducts and two levels of duct insulation) do factor in duct losses.

Because of its positioning, the ductwork (whether insulated or not) contributes less to the heat loss of the longitudinal floor than the transverse floor. There is always some belly blanket insulation below the ducts, but never any above, since the duct takes up almost all of the space in the joist cavity where it is located. Conductive and other duct losses are confined in a relatively small space and a significant portion of the losses leak back into the house. Increasing belly blanket insulation beyond $\mathrm{R}-11$ enhances this effect. 'Adding joist cavity insulation further improves floor thermal performance.

Duct insulation improves the floor system's thermal performance. We calculated the U-factor for the floor system with an R-5 wrap around the duct. (To account for compression of the R-5 wrap, its $R$-value is reduced to $R-4$.) 


\begin{tabular}{|c|c|c|c|c|}
\hline \multicolumn{5}{|c|}{$\begin{array}{l}\text { MAP Longitudinal Floor System U-Factors } \\
\left(\text { Btu/hroft }{ }^{\circ} \cdot \mathrm{F}\right)\end{array}$} \\
\hline $\begin{array}{c}\text { belly/joist } \\
\text { insulation } \\
\text { nominal } \\
\mathrm{R} \text {-value }\end{array}$ & $\begin{array}{l}\text { fioor } \\
\text { framing }\end{array}$ & $\begin{array}{c}\text { steady } \\
\text { state (no } \\
\text { duct } \\
\text { effects } \\
\text { included) }\end{array}$ & $\begin{array}{l}\text { dicts with } \\
\text { R-5 wrap }\end{array}$ & $\begin{array}{l}\text { unin- } \\
\text { sulated } \\
\text { ducts }\end{array}$ \\
\hline $11^{1 / 22}$ & $2 \times 8$ & 0.032 & 0.031 & 0.033 \\
\hline $22 / 19$ & $2 \times 6$ & 0.030 & 0.031 & 0.033 \\
\hline $22 / 22$ & $2 \times 6$ & 0.030 & 0.031 & 0.032 \\
\hline $22 / 21^{\circ *}$ & $2 \times 6$ & 0.029 & 0.030 & 0.031 \\
\hline
\end{tabular}

* Assumes an extra R-7 batt under the duct region.

** High density R-21 batt (5 1/2" thick)

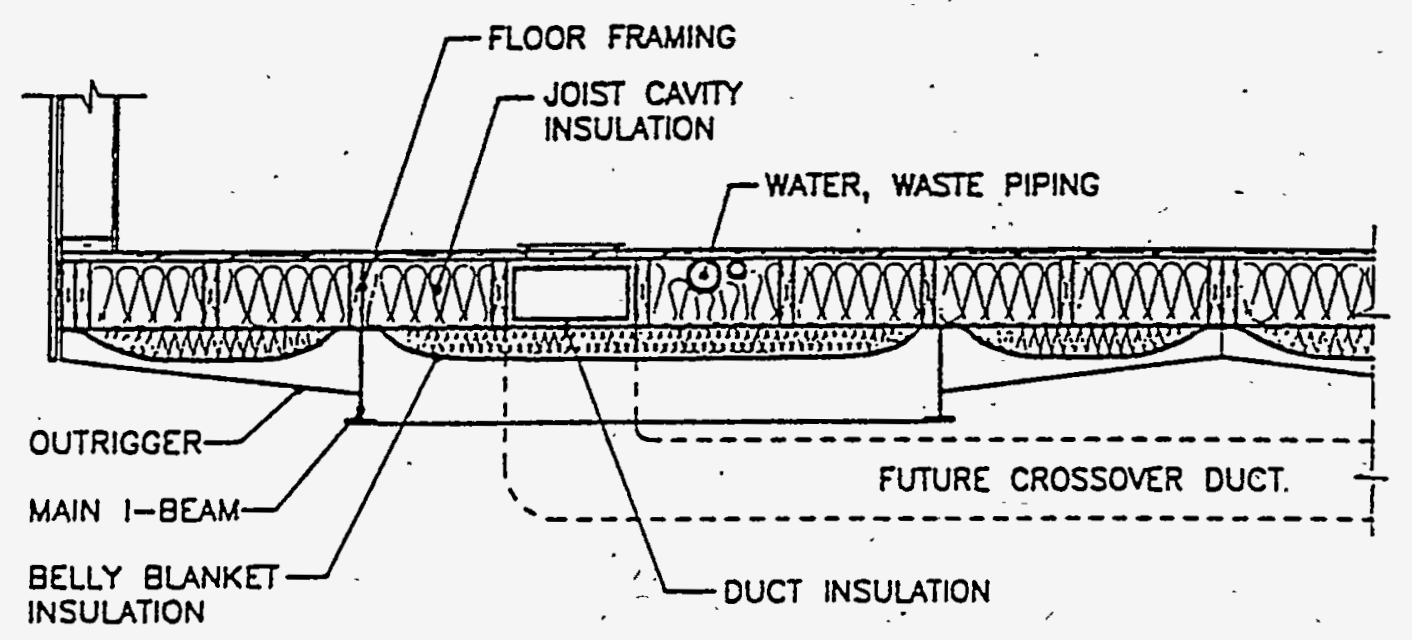




\begin{tabular}{|c|c|c|c|c|}
\hline \multicolumn{5}{|c|}{ Additional Longitudinal Floor System U-Factors } \\
(Btu/hrof' $\bullet$ F) \\
\hline $\begin{array}{c}\text { belly/joist } \\
\text { insulation } \\
\text { nominal } \\
\text { R-value }\end{array}$ & $\begin{array}{c}\text { floor } \\
\text { framing }\end{array}$ & $\begin{array}{c}\text { steady } \\
\text { state (no } \\
\text { duct } \\
\text { effects } \\
\text { included) }\end{array}$ & $\begin{array}{c}\text { ducts with } \\
\text { R-5 wrap }\end{array}$ & $\begin{array}{c}\text { unin- } \\
\text { sulated } \\
\text { ducts }\end{array}$ \\
\hline $11 / 19$ & $2 \times 6$ & 0.037 & 0.039 & 0.042 \\
\hline $14 / 19$ & $2 \times 6$ & 0.035 & 0.036 & 0.038 \\
\hline $11 / 22$ & $2 \times 6$ & 0.036 & 0.038 & 0.041 \\
\hline $14 / 22$ & $2 \times 6$ & 0.034 & 0.035 & 0.038 \\
\hline $11 / 21^{\circ}$ & $2 \times 6$ & $0: 035$ & 0.037 & 0.040 \\
\hline $14 / 21$ & $2 \times 6$ & 0.033 & 0.034 & 0.036 \\
\hline
\end{tabular}

* High density R-21 batt ( $1 / 2$ " thick) 


\section{Duct Model Equations}

\section{I.3 Added Infiltration due to Duct Leakage}

Definitions:

$Q_{\text {odd }}=$ - Infiltration added by duct leakage

$Q_{\text {nes }}=$ Natural infiltration

$Q_{\text {fan }}=$ Air handler fan flow

$F_{p}=$ Remurn leak fraction

$F_{s}=$ Supply leak fraction

$F_{a}=$ Added infiltration as fraction of air handler flow

\section{Equations:}

Basic Equation:

$$
Q_{\text {cos }}=Q_{\text {nat }}+Q_{\text {add }}
$$

Let $F_{\max }=\max \left(F_{r}, F_{s}\right)$

$$
F_{\min }=\min \left(F_{r}, F_{s}\right)
$$

CASE I. Unbalanced fan flow small relative to natural infiltration

$$
\begin{aligned}
\left(F_{\max }-F_{\text {min }}\right) Q_{\text {far }} & \leq 2 Q_{\text {nas }} \\
Q_{\text {add }} & =\left(\frac{1}{2}\left(F_{\text {max }}-F_{\min }\right)+\left(1-F_{\max }\right) F_{\min }\right) Q_{\text {far }} \\
& =F_{a} Q_{\text {fan }}
\end{aligned}
$$

CASE II. Unbalanced fan flow large relative to natural infiltration

$$
\begin{aligned}
& \left(F_{\max }-F_{\min }\right) Q_{\text {fan }} \geq 2 Q_{\text {nas }} \\
& Q_{\text {add }}\left(F_{\max }-F_{\min }+\left(1-F_{\max }\right) F_{\min }-\frac{Q_{\text {nat }}}{Q_{\text {fan }}}\right) Q_{\text {fan }} \\
& =F_{a} Q_{\text {fan }}
\end{aligned}
$$




\section{Duct Model Equations}

\section{4 Heat Loss due to Duct Leakage}

\section{Assumptions:}

- Air handler return leaks are at outdoor temperanure

- Air handler supply leaks are at furnace exit temperature

\section{Definitions:}

$E_{a}=$ Added heat loss due to duct leakage $(\mathrm{Btu} / \mathrm{h})$

$E_{f}=$ Output of furnace (Btu/h)

$\Delta T_{f}=\frac{E_{f}}{60 \rho C_{p} Q_{\text {fan }}}=$ Temperature rise across fumace $(F)$

- $\frac{E_{a}}{E_{f}}=$ Efficiency loss of fumace

$\Delta T_{h}=$ delta $T$ of house $(F)$

$60 \rho C_{p}=1.08$ for standard air $(B t u / F \cdot h \cdot c f m)$

Efficiency Loss:

$$
\frac{E_{a}}{E_{f}}=F_{a} \frac{\Delta T_{h}}{\Delta T_{f}}+F_{s}
$$

Example: $\quad$ At design conditions $\Delta T_{\dot{n}} \sim \Delta T_{\text {f }}$

$$
\text { Assume }\left(F_{\max }-F_{\min }\right) Q_{\text {jan }}<2 Q_{\text {nas }}
$$

1) $10 \%$ return leak $F_{p}=.10$

$$
F_{a}=.05
$$

$$
\frac{E_{a}}{E_{f}}=.05
$$

2) $10 \%$ supply leak $F_{s}=.10$

$$
F_{a}=.05
$$

$$
\frac{E_{a}}{E_{f}}=.15
$$

3) $5 \%$ returi leak, $5 \%$ supply leak $F_{s}=.05, F_{s}=.05$

$$
F_{a}=.0475
$$$$
\frac{E_{a}}{E_{f}}=.0975
$$ 